\title{
The formation of authigenic deposits during Paleogene warm climatic intervals: a review
}

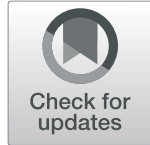

Santanu Banerjee ${ }^{1 *} \mathbb{D}$, Tathagata Roy Choudhury ${ }^{1}$, Pratul Kumar Saraswati ${ }^{1}$ and Sonal Khanolkar ${ }^{2}$

\begin{abstract}
Although Paleogene warm climatic intervals have received considerable attention for atmospheric and oceanographic changes, the authigenic mineralization associated with these time spans remains overlooked. An extensive review of the literature reveals a close correspondence between the high abundance of glauconite and warm climatic intervals during the Paleogene period. The abundance of phosphorite, ironstone, lignite and black shale deposits reveals similar trends. Although investigated thoroughly, the origin of these authigenic deposits is never understood in the background of Paleogene warming climatic intervals. A combination of factors like warm seawater, hypoxic shelf, low rate of sedimentation, and enhanced rate of continental weathering facilitated the glauconitization. The last factor caused the excess supply of nutrients, including $\mathrm{Fe}, \mathrm{Si}, \mathrm{K}, \mathrm{Mg}$ and $\mathrm{Al}$ through the rivers, the cations needed for the formation of glauconite. The excessive inflow of nutrient-rich freshwater into the shallow seas further ensured high organic productivity and stratification in shallow shelves, causing hypoxia. The consequent rapid rise in sea-level during the warm periods created extensive low-relief shallow marine shelves starved in sediments. Oxygen-deficiency in the shallow marine environment facilitated the fixation of Fe into the glauconite structure. The inflow of nutrient-rich water during the warm climatic intervals facilitated the formation of phosphorite, ironstone, and organic-matter-rich sedimentary deposits as well. Although global factors primarily controlled the formation of these authigenic deposits, local factors played significant roles in some of the deposits. Therefore, phosphorites formed in marine conditions with open circulation within the tropical zone. While lush growth of rainforest covers in the tropical belt facilitated the formation of coastal lignite.
\end{abstract}

Keywords: Warm climatic intervals, Hyperthermal events, Glauconite, Phosphorite, Oolitic ironstone, Lignite, Hypoxia, Paleogene

\section{Introduction}

The Paleogene period witnessed several global hyperthermal events (Zachos et al. 2001). Out of them, the most significant had been that took place at the end of the late Paleocene and the beginning of early Eocene intervals when the seawater temperature rose by about $4{ }^{\circ} \mathrm{C}$ (Jenkyns 2003; Hessler et al. 2017). These hyperthermal events were triggered by an enhanced supply of greenhouse gases that ushered rapid evolutionary and/or environmental turnovers. These events are marked by records of sharp sea-level rise, ocean de-

\footnotetext{
* Correspondence: santanu@iitb.ac.in

'Department of Earth Sciences, Indian Institute of Technology Bombay,

Powai, Mumbai 400076, India

Full list of author information is available at the end of the article
}

oxygenation (Sluijs et al. 2014 and references therein), shoaling of the calcite compensation depth (CCD), enhanced hydrological and weathering cycles (Nicolo et al. 2007) and increased supply of kaolinite to the marine realm (Gibson et al. 2000 and references therein). Several studies link the formation of authigenic minerals to sea-level changes in sequence stratigraphic context (Morad et al. 2012). On the contrary, the role of seawater temperature and composition on authigenic mineral formation representing the 'greenhouse world' is rarely investigated beyond carbonate sediments. This paper finds a correlation of authigenic mineralization with the fluctuations in global seawater temperature. It points out marked enhancement in authigenic 
mineralization in marine sediments during Paleogene warm climatic intervals.

Glauconite formed abundantly during the Paleogene, constituting up to $24 \%$ of the total record (Banerjee et al. 2016a). Recently Bansal et al. (2019) attributed the high abundance of glauconite in the Upper Cretaceous to a combination of factors like high sea-level, enhanced continental weathering in warm and humid climatic conditions and oxygen depletion on shelf seas. However, because of the lack of biostratigraphic control, these authors could not relate the abundance of the Upper Cretaceous glauconites to specific geological events. Therefore, it is unclear whether the glauconite is distributed evenly within the Late Cretaceous, or it is restricted to specific time intervals. Palaeo-oceanographic conditions of the Late Cretaceous time largely continued in the Paleogene (Jenkyns 2003). The biostratigraphically constrained sections in the Paleogene provide an opportunity to explore whether the occurrence of glauconite depended on subtle changes in palaeo-oceanographic conditions corresponding to warm climatic intervals. Phosphorite is a common associate of the Late Cretaceous glauconites, particularly Tethyan deposits (Banerjee et al. 2019). Lignite, phosphorite, and ironstone deposits of commercial importance are well known in the Paleogene sedimentary succession. However, the relationship between the abundance of these minerals and hyperthermal events is never investigated. This paper aims to present the commonalities of authigenic minerals formed during the Paleogene warm climatic intervals. Although the focus of this study is on glauconitization, phosphorite, ironstone, and lignite formation are also considered. To this effect, a thorough review has been presented.

\section{Global record of hyperthermal events}

Paleogene time represents a complex evolution of Earth's climate bracketed within the overall warmer Cretaceous to colder Neogene transition (Zachos et al. 1993). Deep-sea benthic foraminiferal $\delta^{18} \mathrm{O}$ and $\delta^{13} \mathrm{C}$ values reveal extreme warming during the Paleogene (Zachos et al. 2001). Short-lived ( $200 \mathrm{kyr})$ events of rapid climatic shifts characterize the Paleogene climate. The 'hyperthermal' events coincide with negative carbon isotopic excursions (CIEs) (Fig. 1; Cramer et al. 2003; Nicolo et al. 2007; Stap et al. 2009; Zachos et al. 2010). The negative CIE implies a rapid delivery of isotopically depleted carbon into marine shelves and the rise of $p \mathrm{CO}_{2}$ in the atmosphere subsequently. The climatic transitions during the Paleogene had a severe impact on the biosphere and lithosphere. Microfossil records show severe decline and diversifications in pelagic and open marine ecosystems during these thermal events (e.g.,
Thomas 1998; Crouch et al. 2001; Kelly 2002; Khanolkar and Saraswati 2019).

Early Paleogene time records warming of Earth's surface in the period from late Paleocene (ca. $59 \mathrm{Ma}$ ) to early Eocene (ca. $52 \mathrm{Ma}$ ). Most of the hyperthermal events viz. the Paleocene-Eocene thermal maximum (PETM) or H-1 (Cramer et al. 2003) and the Eocene thermal maximum 2 (ETM2) or Eocene layers of mysterious origin (ELMO) (Lourens et al. 2005) and the Eocene thermal maximum 3 (ETM3) or H2 or "X" event (Nicolo et al. 2007; Stap et al. 2010; Zachos et al. 2010), besides several short-lived climatic perturbations viz. I1 and I2 (Cramer et al. 2003; Nicolo et al. 2007), belong to this period. These hyperthermal events belong to three warm climatic intervals (Fig. 1). The early Paleogene warming interval includes the early late Paleocene event (ELPE, Bralower et al. 2002), also known as midPaleocene biotic event (MPBE, Bernaola et al. 2007), and the latest Danian event (LDE, Bornemann et al. 2009) in the Paleocene, and PETM, ETM2, ETM3 and EECO (early Eocene climatic optimum) in the early Eocene. A 17 Myr of cooling trend succeeds upwards and is interrupted by another warm climatic interval incorporating the middle Eocene climatic optimum (MECO) during the early Bartonian (Fig. 1). It is followed upwards by a long-term cooling trend that continues till the early Oligocene, as the arctic ice-sheets formed. A short-lived warming interval incorporates the late Oligocene warming event (LOWE), representing the last hyperthermal event during the Paleogene (Zachos et al. 2001). The Paleocene hyperthermal events viz. Dan C2-event, latest Danian event (LDE), and early late Paleocene event (ELPE) have received less attention compared to the hyperthermal events in the Eocene (Schulte et al. 2013).

\section{Paleogene authigenic mineral formation 3.1 Occurrence of glauconite}

Our study presents 124 Paleogene glauconite occurrences that formed principally in four major continents/ zones, and these account for $>90 \%$ of the total global record of this time (Table 1; Fig. 2). These zones are: A) North American continental margin (eastern and western coastal plain deposits); B) Palaeo-Tethys, including northern Africa, parts of southern Europe, Middle East and India to the east; C) Palaeo-North Sea, extending from the United Kingdom to the west to northern Germany in the east; and D) High southern latitudes, including New Zealand eastern Tasman Plateau and Argentina (Figs. 2, 3, 4, 5, 6). Paleogene glauconite also occurs in places in Africa, including Ivory Coast, Nigeria and South Africa, and Asia, including Russia, China and Japan. The majority of the glauconite deposits formed on the well-developed continental margin on the northern hemisphere. 


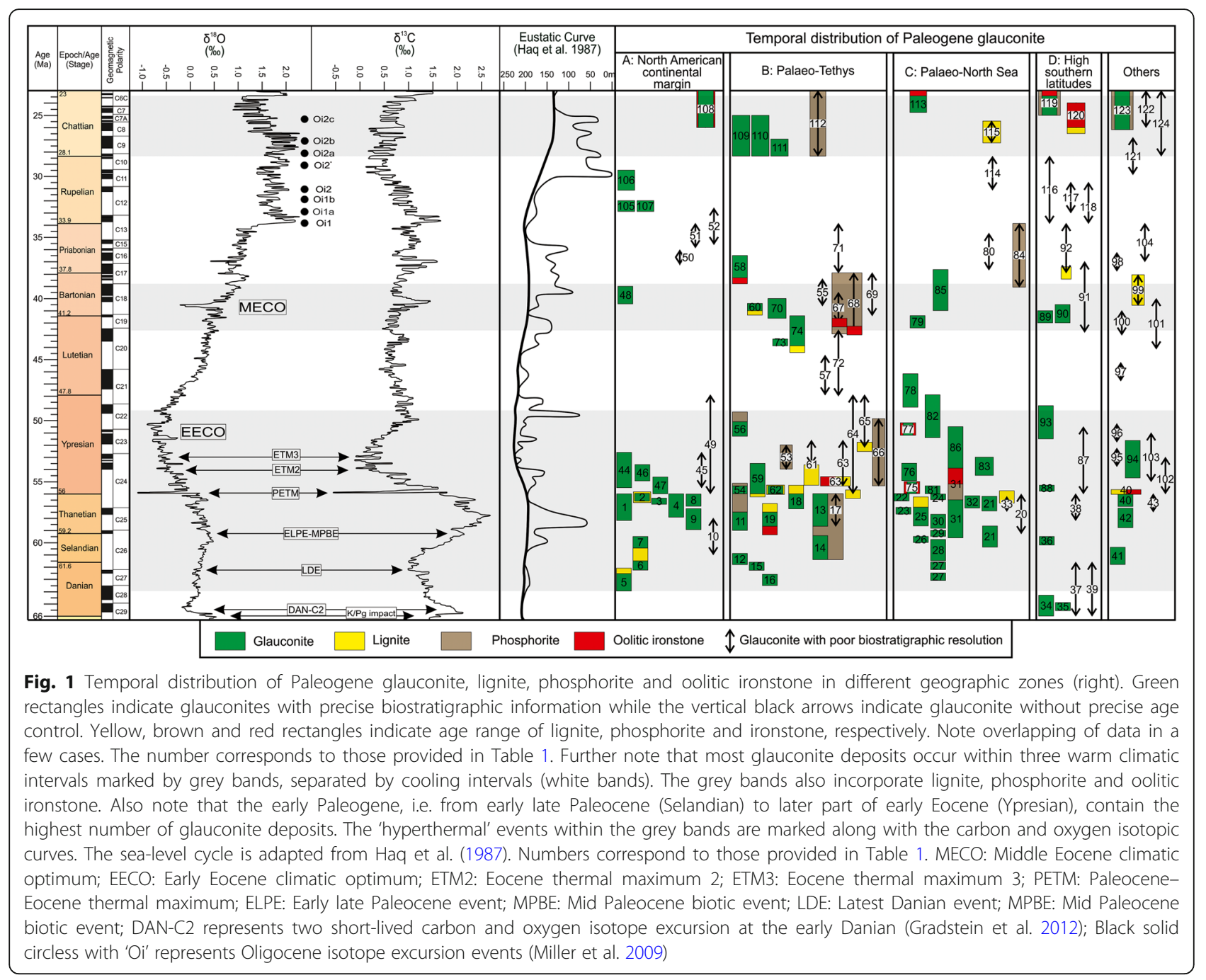

Out of 124 occurrences, approximately 55\% have reliable age control, biostratigraphic or radiometric. Therefore, they are presented separately from those not having similar age constraints in Fig. 1. The stratigraphic distribution of glauconite during the Paleogene shows a nonuniform trend (Fig. 1). Eocene, Paleocene, and Oligocene record $49 \%, 35 \%$, and $16 \%$, respectively, of total glauconite occurrences (Table 1; Fig. 1). These time intervals also included the hyperthermal events of the Paleogene (Fig. 1). The occurrence of the age-constrained glauconites coincides with three bands of warm climatic intervals discussed earlier, while the cooler intervals alternating with them have negligible glauconite occurrences (Fig. 1).

\subsection{Glauconite-phosphorite association}

Phosphorite deposits of economic significance are associated with glauconitic sandstone, siltstone and shale (Banerjee et al. 2019 and references therein; Boukhalfa et al. 2020). Our study reveals a cluster of glauconite- phosphorite deposits along the palaeo-Tethyan margins (Figs. 2, 3, 4, 5; see also Soudry et al. 2006). The cooccurrence of glauconite and phosphorite is reported in 17 cases, all of which correspond to the Paleogene warm climatic intervals (Fig. 1).

Extensive Paleocene-early Eocene phosphorite deposits occur along the northern margin of the African continent (Lucas and Prévôt-Lucas 1995; Soudry et al. 2006; Kechiched et al. 2018) (Figs. 3, 4). These deposits represent the so-called 'Tethyan phosphorites' (Soudry et al. 2006). Broadly similar lithology defined by clays, marls, dolomite, and foraminiferal limestone hosts phosphorites in these basins. Phosphorites deposited in low palaeo-latitudes $\left(<30^{\circ}\right)$ in Tunisia and Algeria (Kouwenhoven et al. 1997; Messadi et al. 2016; Garnit et al. 2017; Kechiched et al. 2018) (Fig. 3). During the early Eocene, phosphorite-rich sediments, hosting glauconite, extended towards the north in shallow marine deposits of Germany (Dill et al. 1996), and to the east in Dababiya Quarry Member in Egypt (Metwally and Mahfouz 2018) (Fig. 4). During the middle to late Eocene, the locus of 


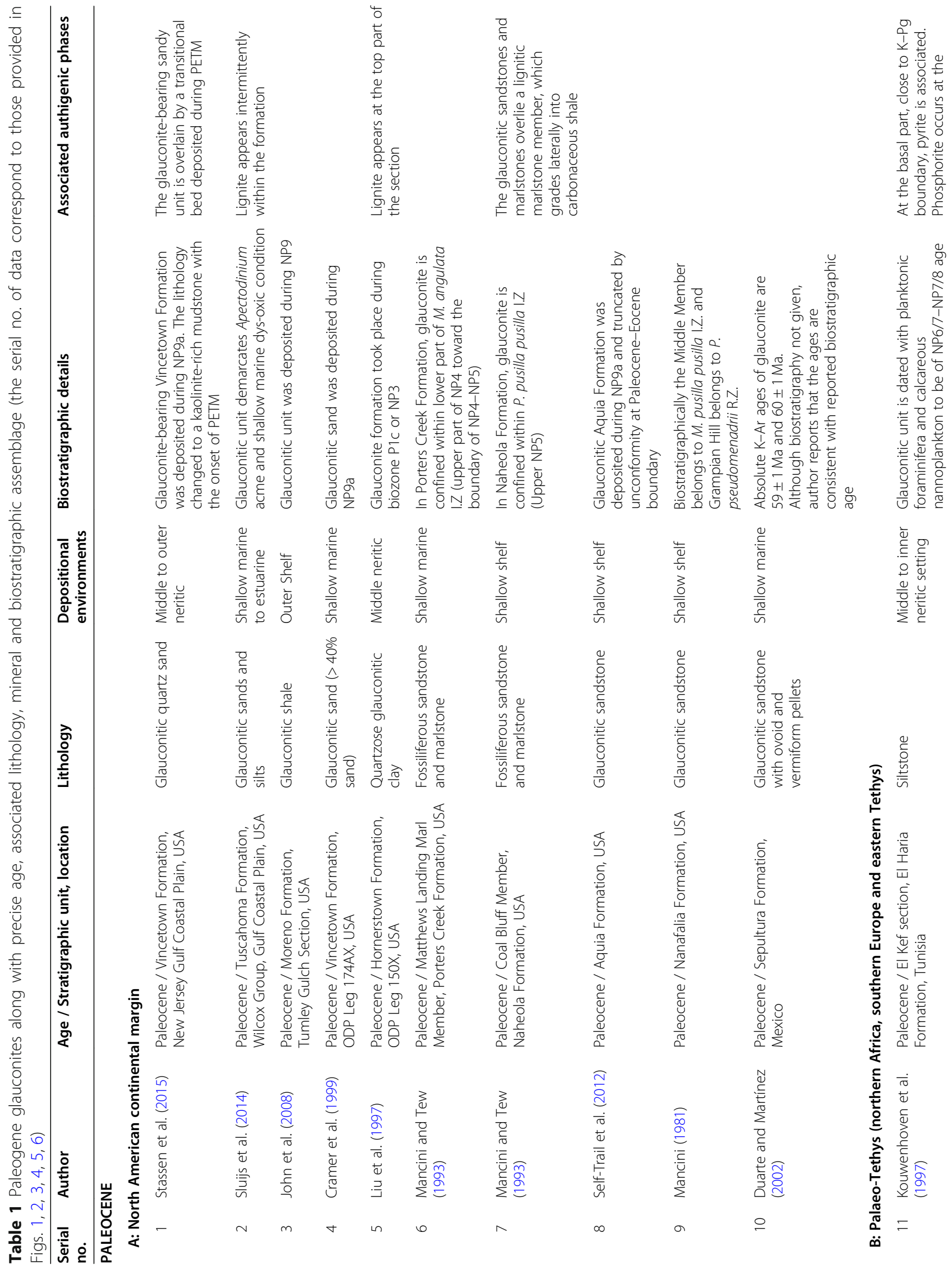




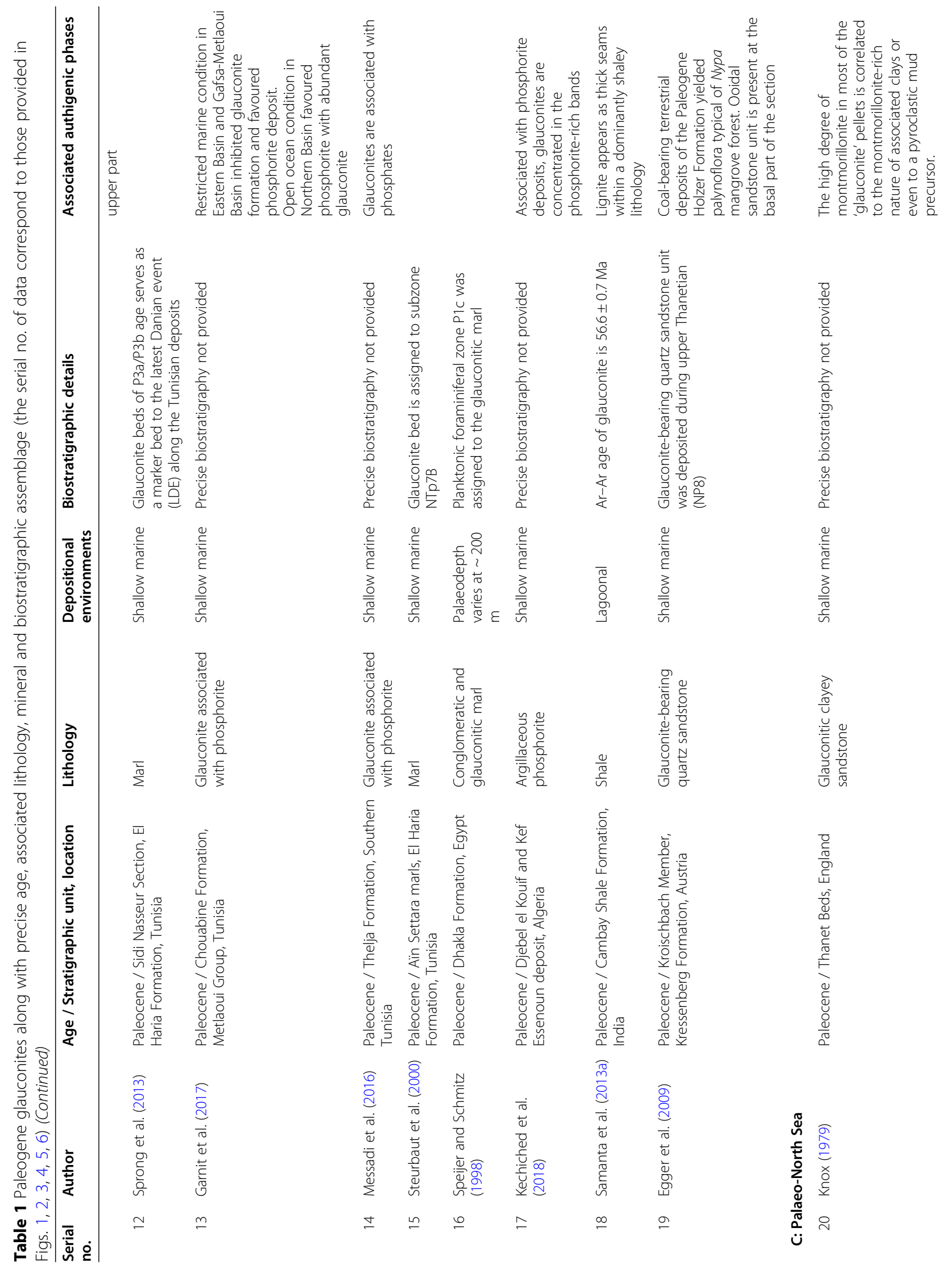




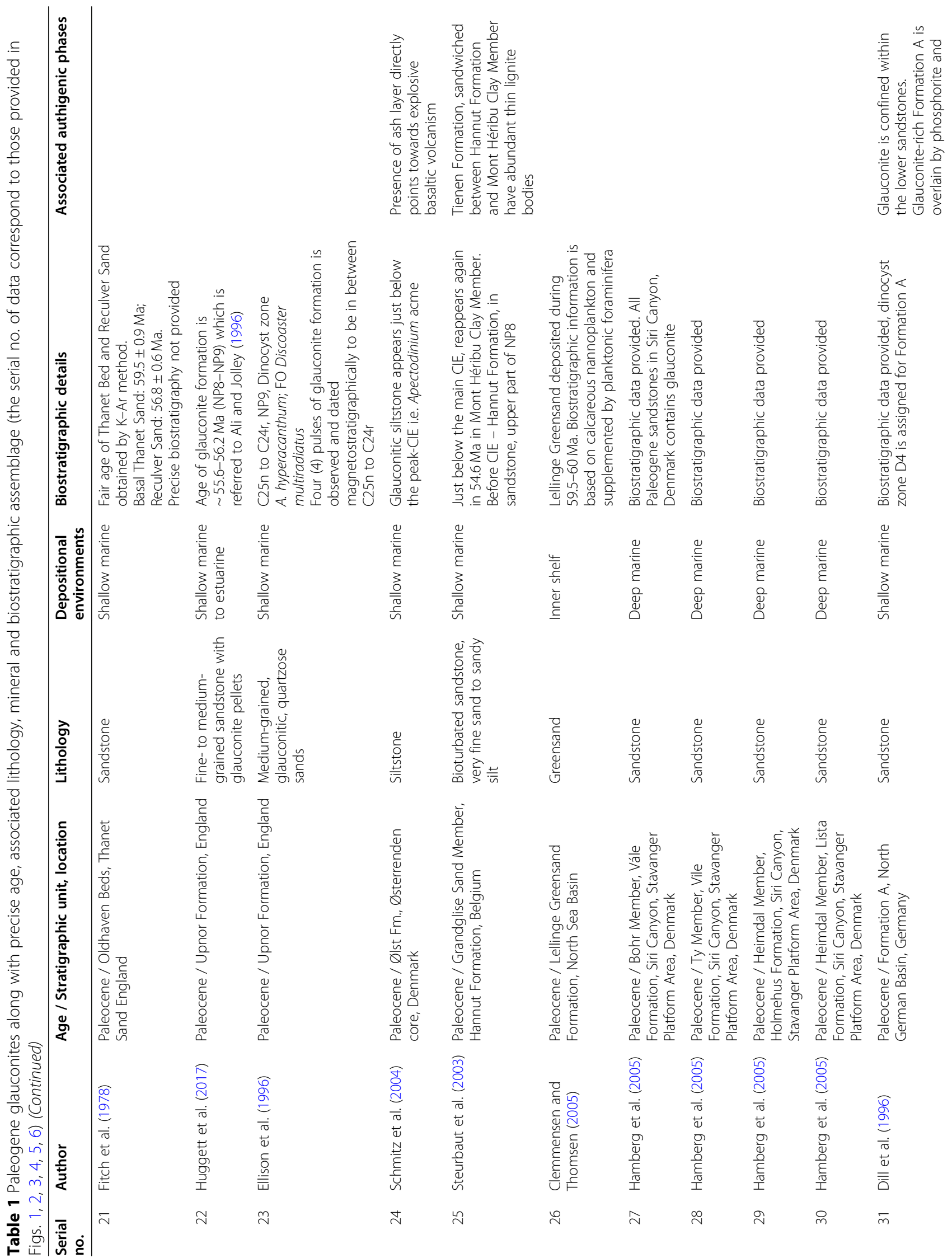




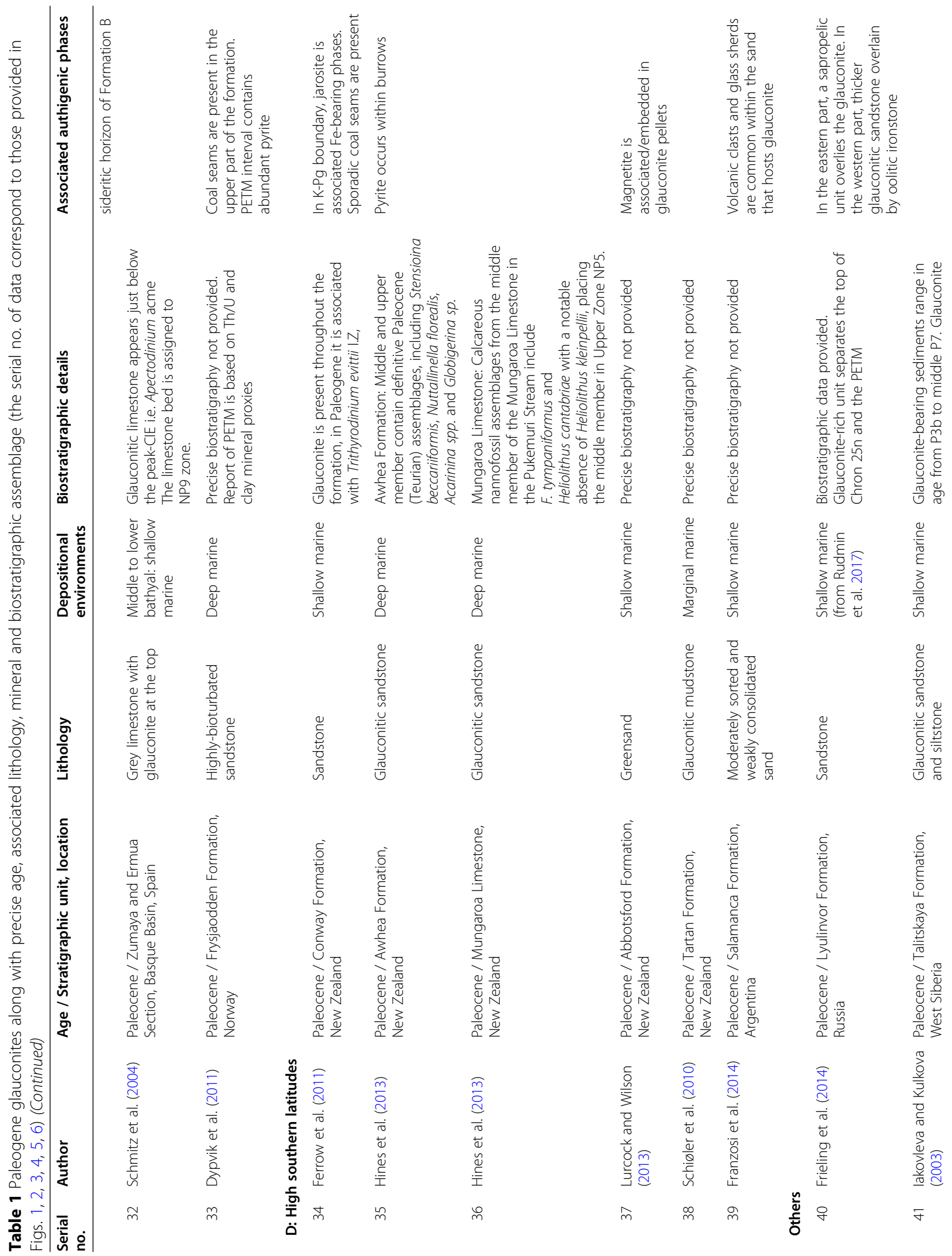




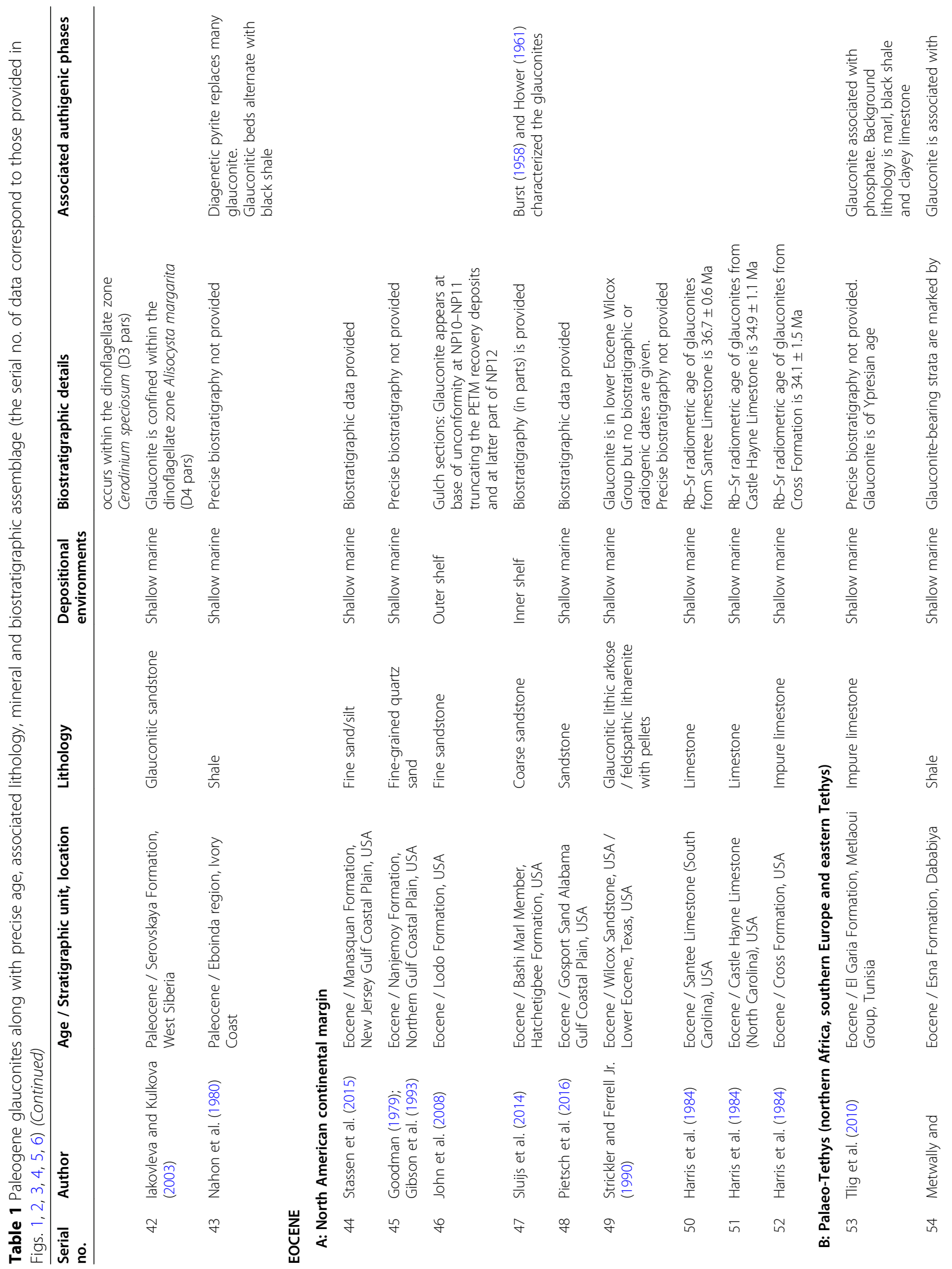




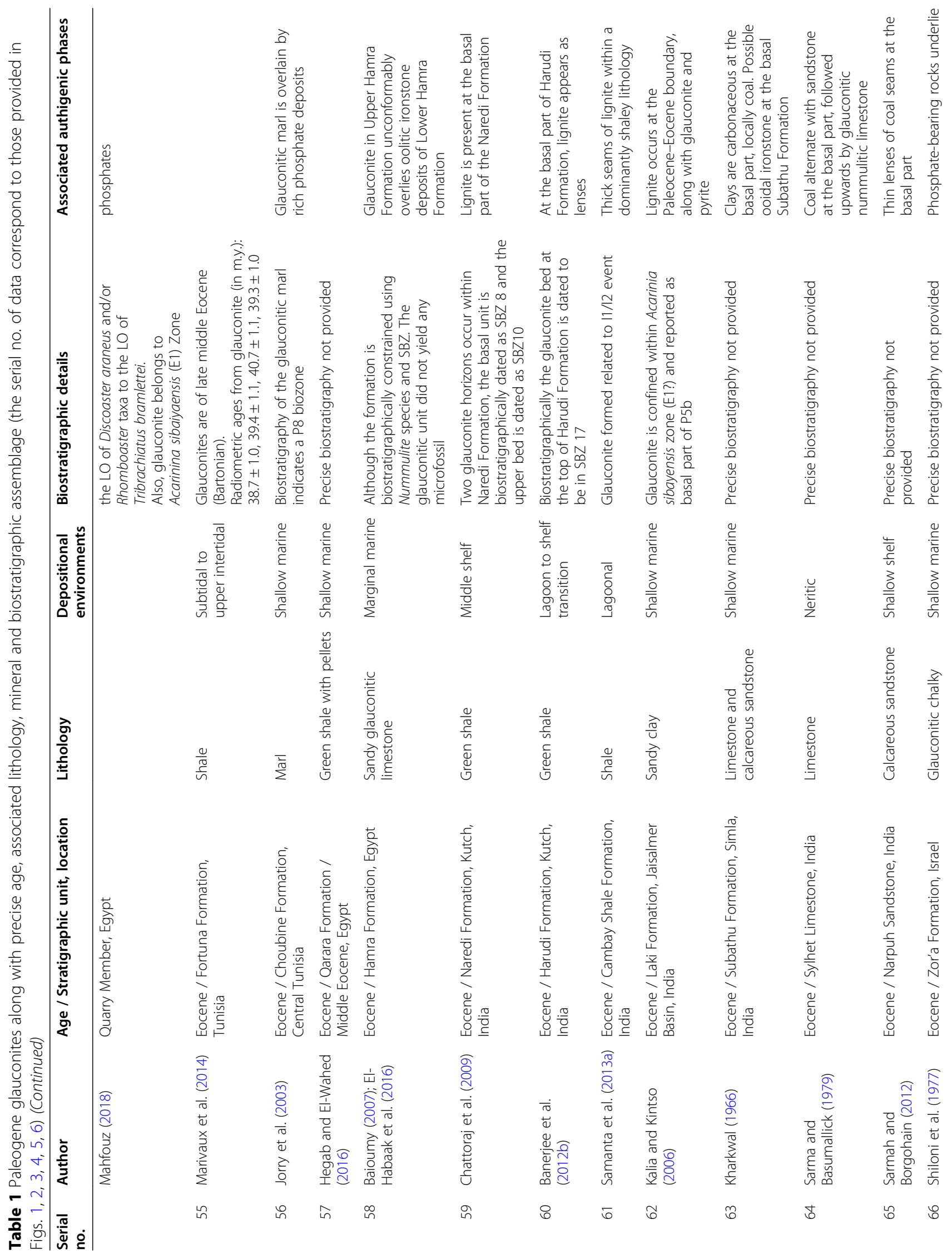




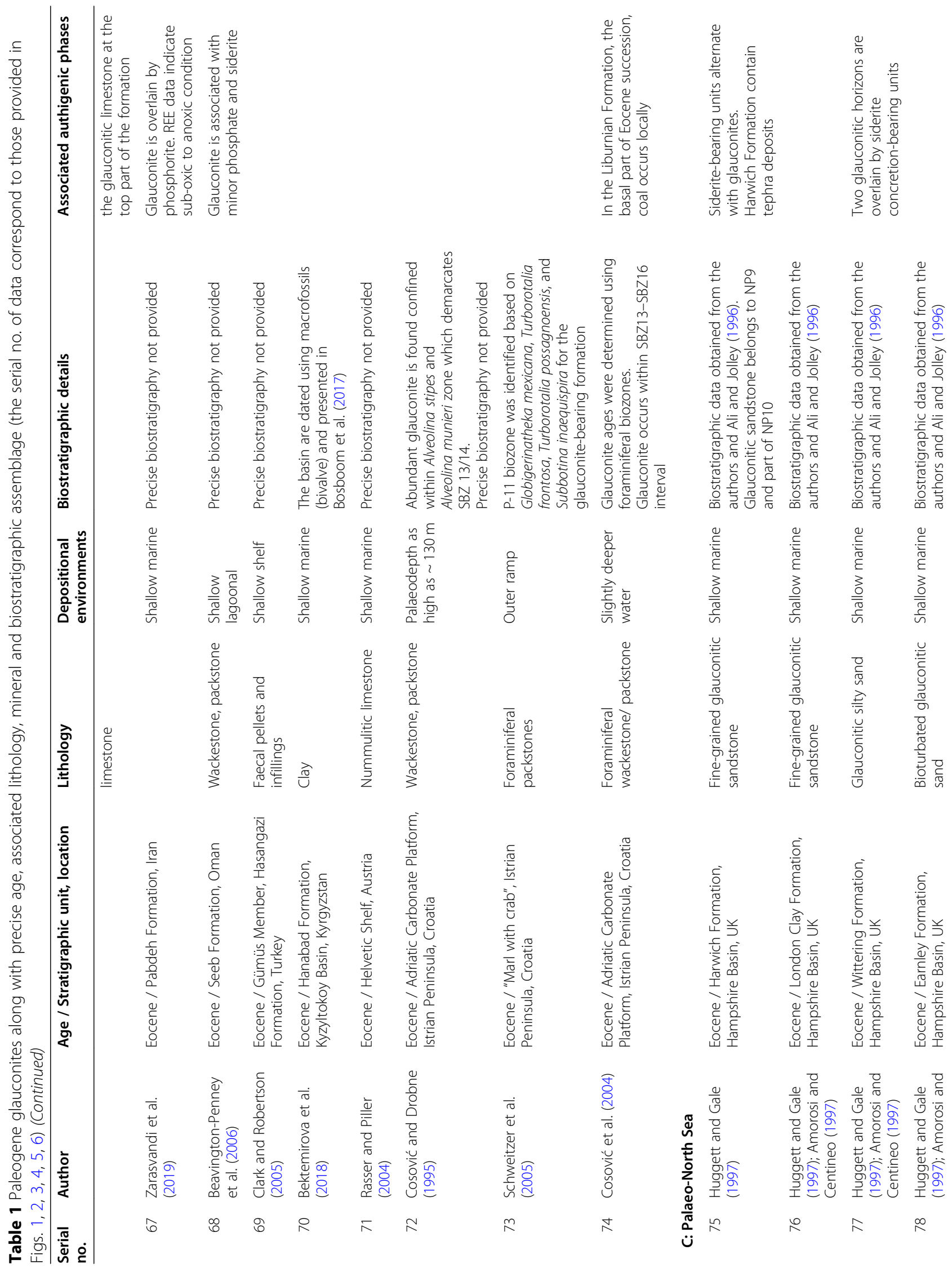




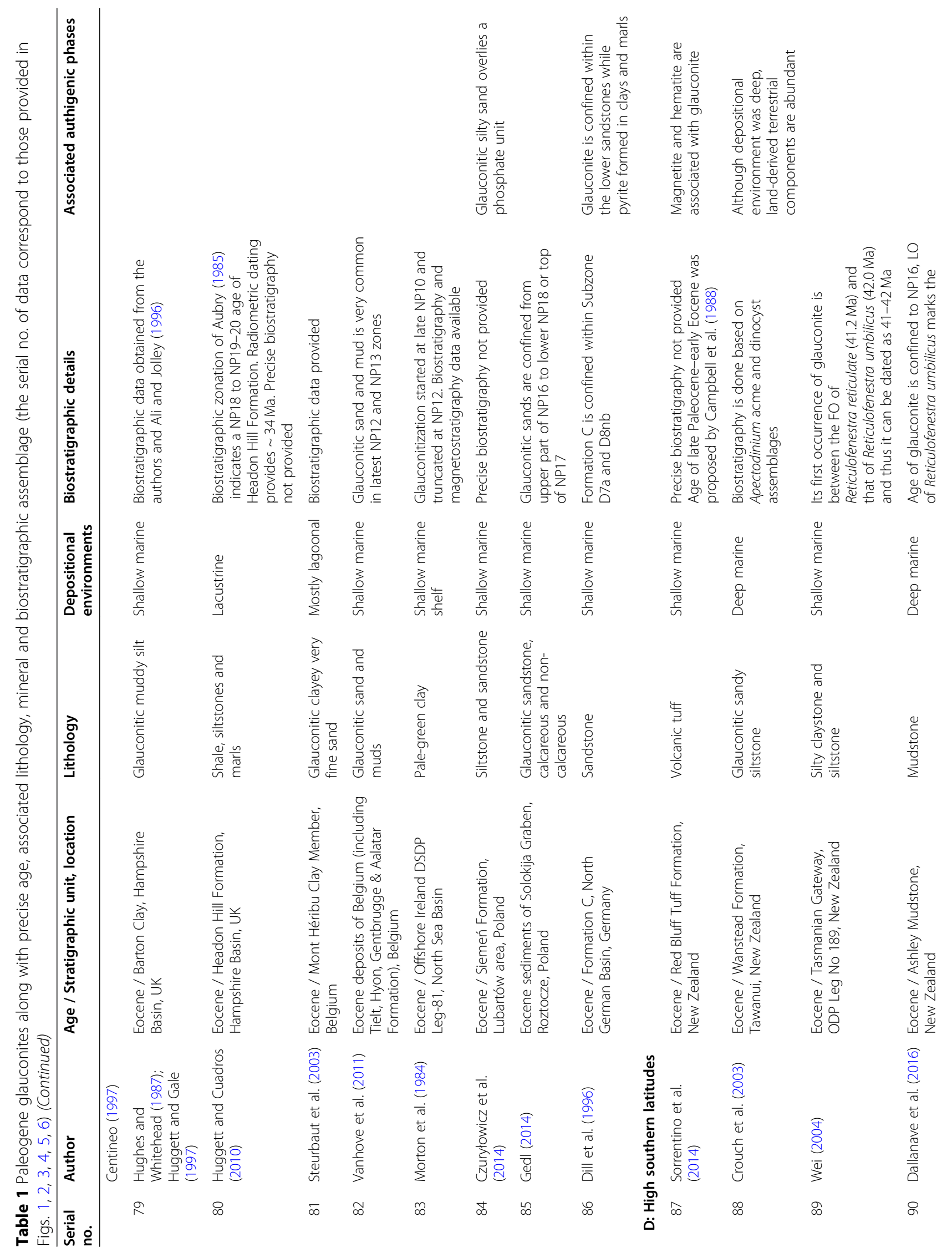




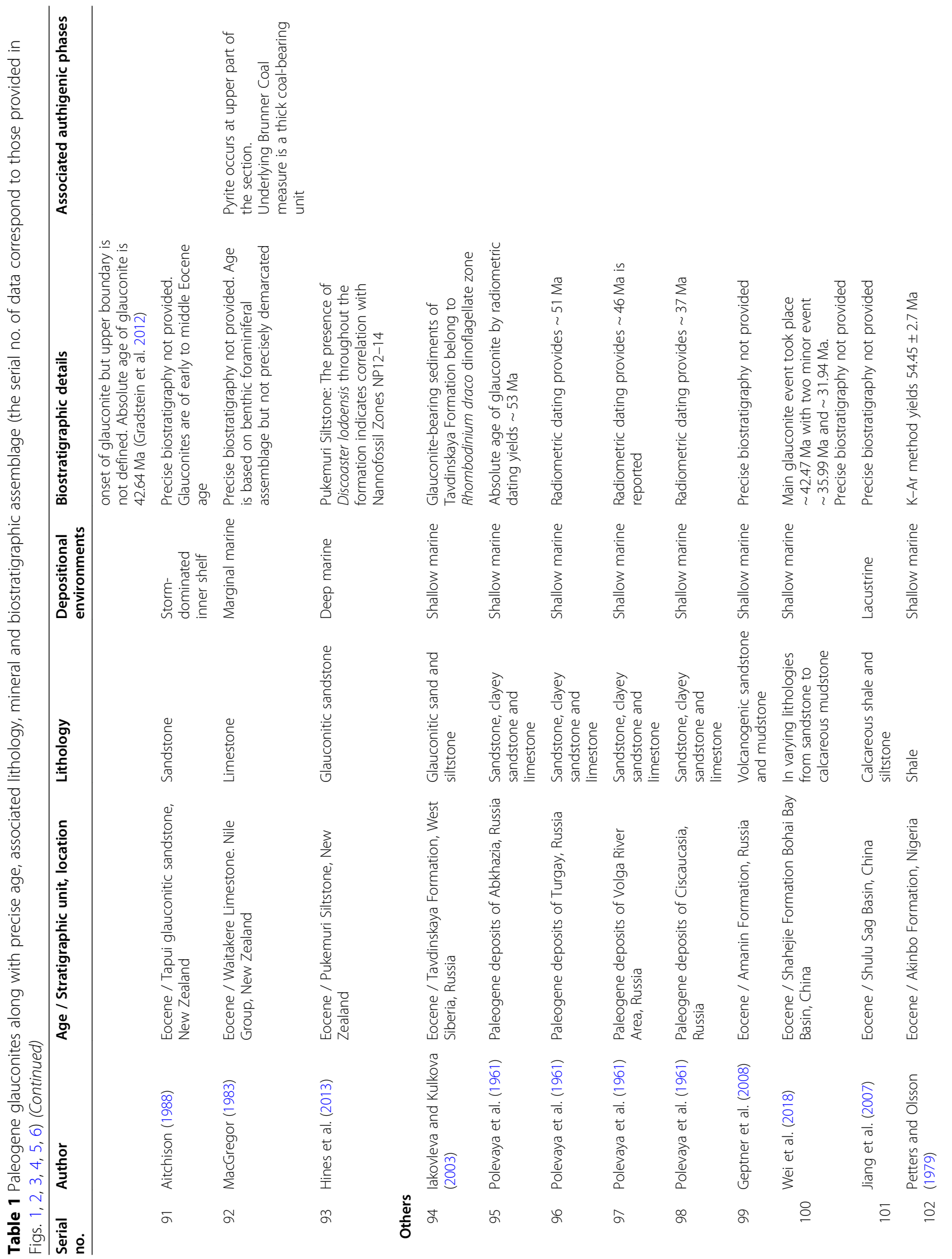




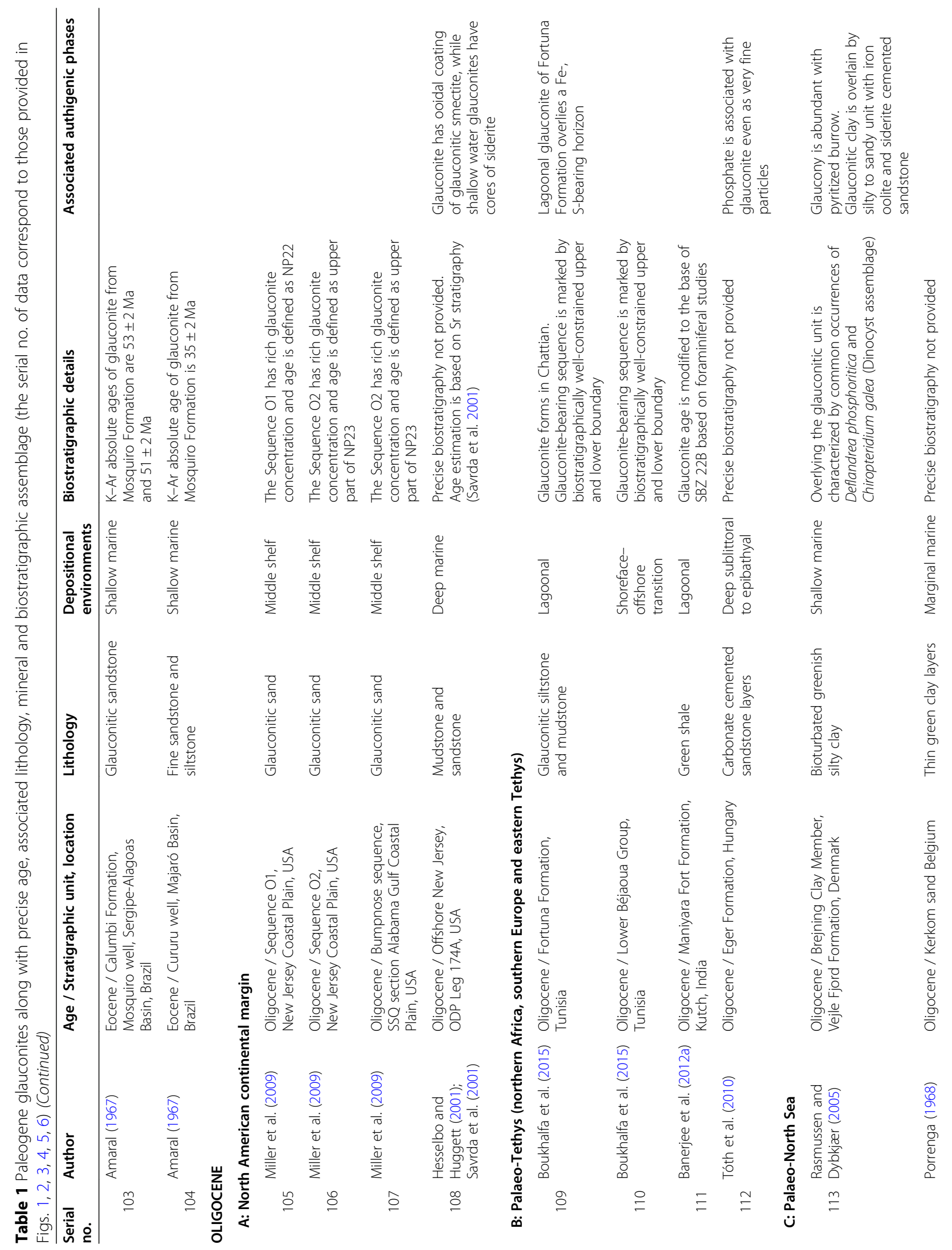




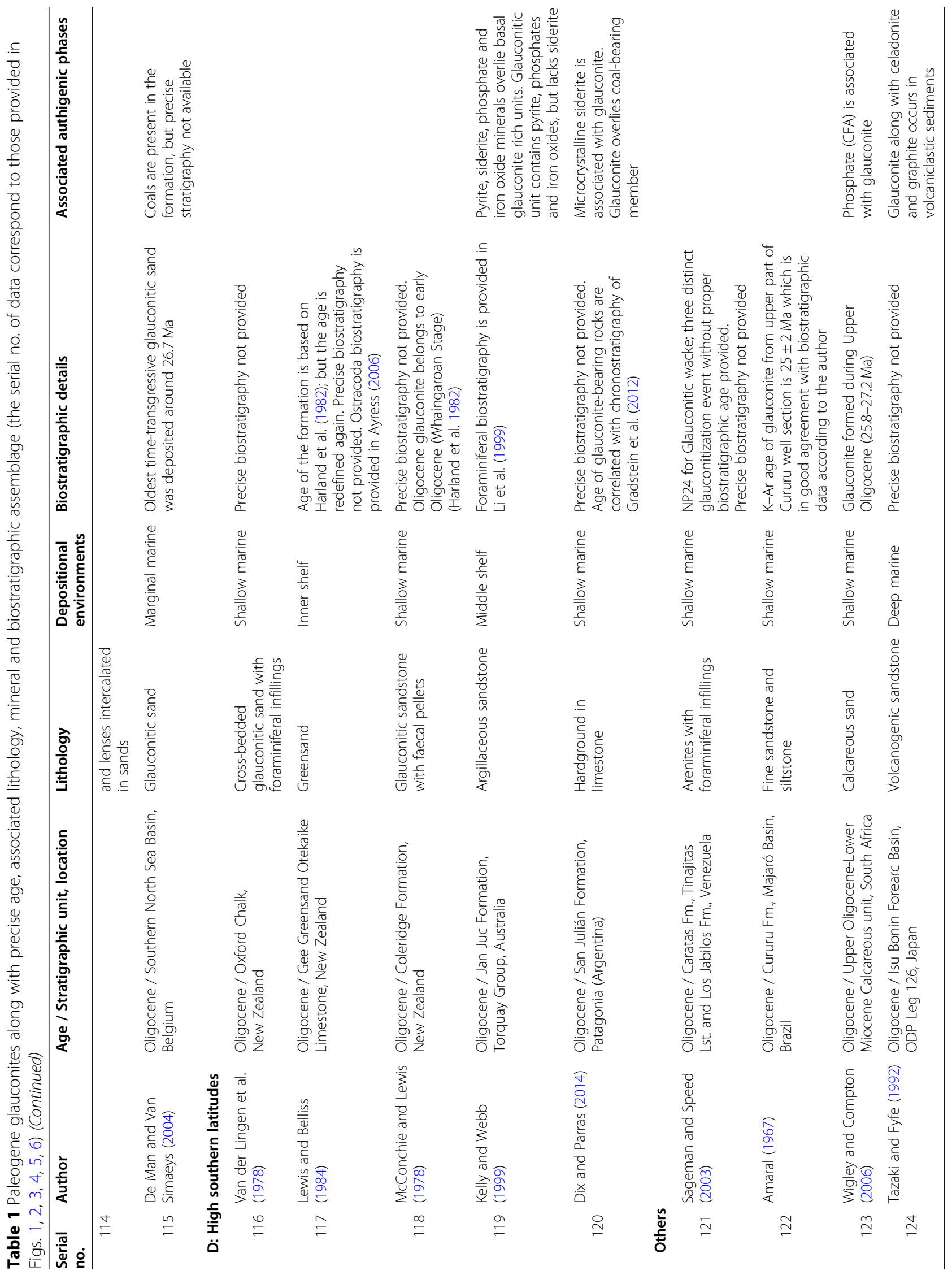




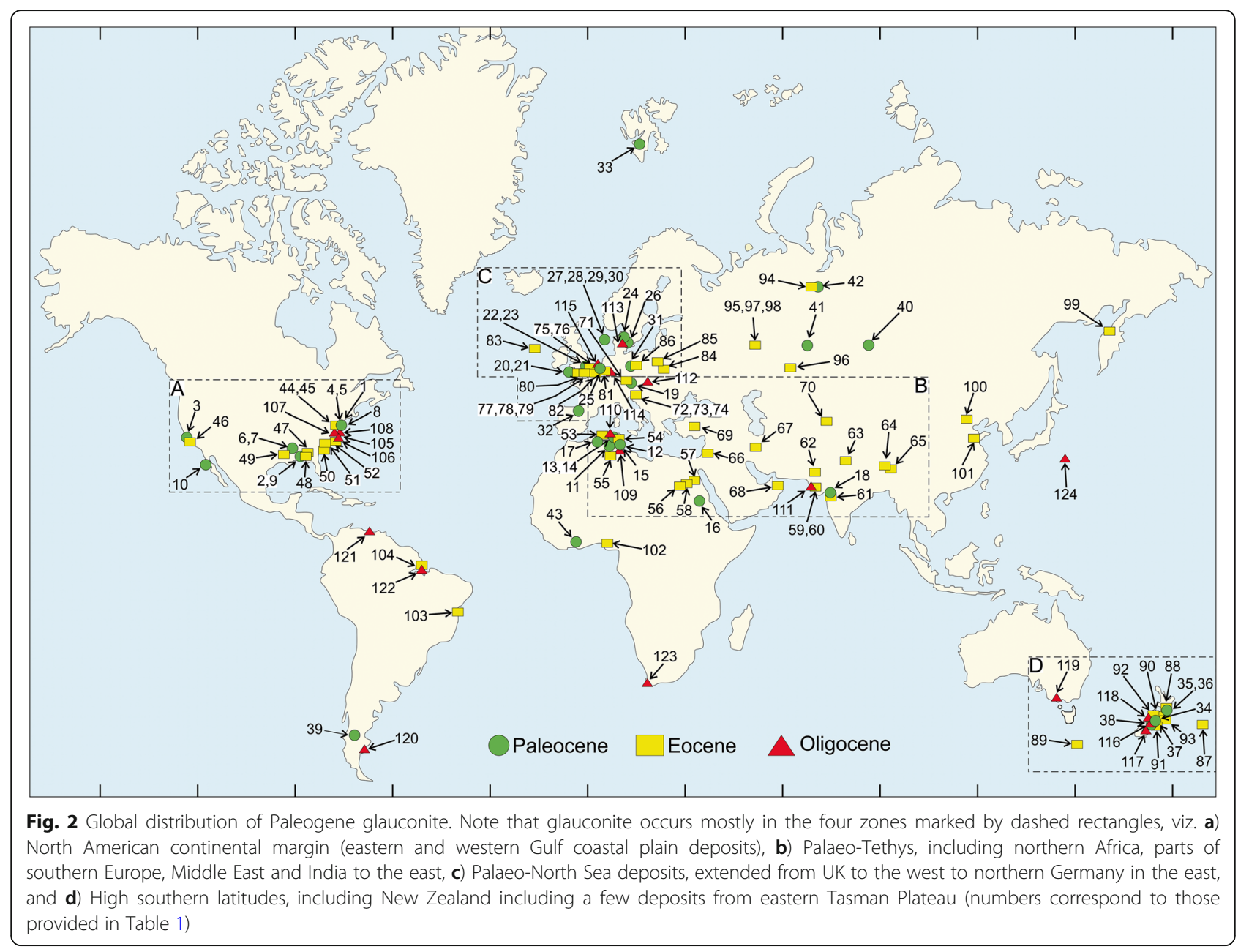

phosphorite deposition shifted towards the eastern and northern parts of the Tethyan domain (Fig. 5). The deposition of phosphorite took place in Iran and in Oman (Beavington-Penney et al. 2006; Zarasvandi et al. 2019) and in Poland (Czuryłowicz et al. 2014). Phosphorite deposition was less common in the Oligocene. Besides the Tethyan margin, glauconite and phosphorite deposits formed within the Oligocene succession of Australia and South Africa (Kelly and Webb 1999; Wigley and Compton 2006; Tóth et al. 2010) (Fig. 6). Throughout the Paleogene, most of the phosphorite-glauconite association was restricted to arid paleoclimate, low-latitudinal passive margin settings (Figs. 3, 4, 5, 6).

\subsection{Glauconite-lignite association}

Lignite is a common deposit of the Paleogene time (Table 1; Fig. 1). The formation of Paleogene lignite overlaps with glauconite within the warm climatic intervals (Fig. 1). Paleogene glauconite occurs in the same stratigraphic succession with economically exploitable lignite in 15 cases. During the Paleocene, lignites formed within a short span of $\sim 10 \mathrm{Ma}$ from late Danian to late Lutetian (Mancini and Tew 1993; Liu et al. 1997; Steurbaut et al. 2003; Egger et al. 2009; Ferrow et al. 2011; Samanta et al. 2013a; Sluijs et al. 2014). The oldest record of the lignite-glauconite association from North American Gulf Coastal Plain deposits corresponds to the Danian-Selandian transition (Fig. 1). At the PaleoceneEocene transition, lignite formed even at high palaeolatitudes in Svalbard, Norway (Dypvik et al. 2011) (Fig. 3). The late Paleocene and middle Eocene lignite-glauconite associations are best developed in the eastern margin of Tethys (Figs. 3, 4). Lignite formed in restricted marine conditions (Chattoraj et al. 2009; Saraswati et al. 2014, 2018). The glauconite-lignite association reduced abruptly during middle and late Eocene (Fig. 1). During the late Oligocene, lignite-glauconite association was restricted only to palaeo-North Sea basin (De Man and Van Simaeys 2004) (Fig. 5). Lignites formed in humid, tropical to boreotropical, and even warm temperate climatic conditions favoring lush growth of vegetation (Figs. 3, 4, 5, 6). Most lignite-glauconite occurrences of high northern latitudes coincide with the Paleocene- 


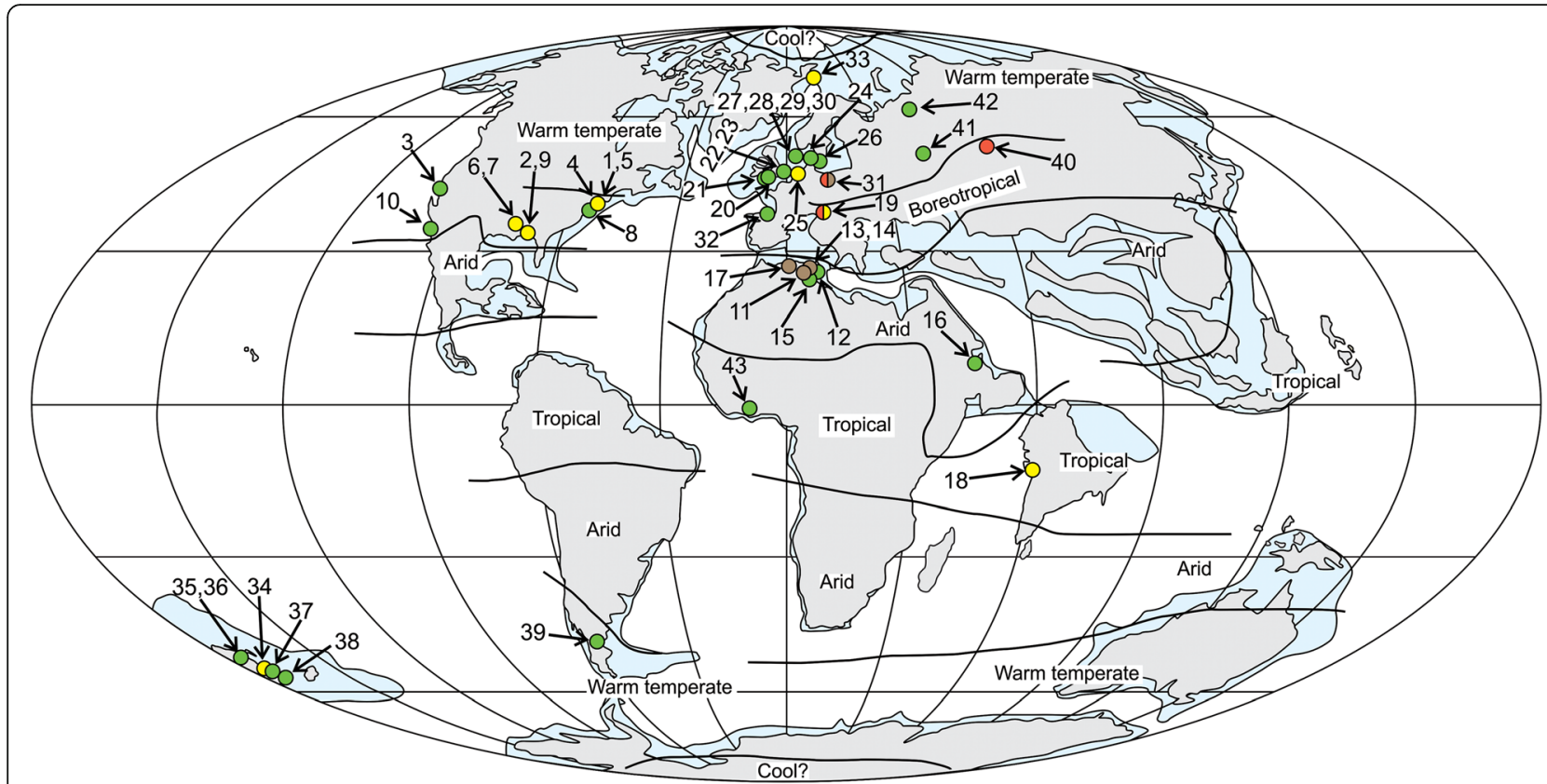

Glauconite

Phosphorite-glauconite association

Lignite-glauconite association

Oolitic ironstone-glauconite association

Phosphorite-oolitic ironstone-glauconite association

\section{Lignite-oolitic ironstone-glauconite association}

Fig. 3 Palaeogeographic map of Paleocene showing distribution of glauconite-phosphorite, glauconite-lignite and glauconite-oolitic ironstone associations (adapted from Boucot et al. 2013). Note that extensive glauconite-phosphorite association formed along the northern margin of African shelf. Further note that glauconite-lignite association remained confined to tropical climatic zones (numbers correspond to those provided in Table 1)

Eocene transition, but it is restricted to middle Eocene in Russia and late Oligocene in Belgium (Table 1; Figs. 5, 6). At high southern latitude lignite is devoid of glauconite during the Paleocene and early Eocene.

\subsection{Glauconite-oolitic ironstone association}

Oolitic ironstone deposits contain $\sim 5 \%$ iron oolith/ooid and more than $15 \%$ iron, with goethite, siderite, chamosite, odinite, and berthierine as chief iron-bearing minerals (Rudmin et al. 2019). The majority of the oolitic ironstone of the Cenozoic time preferably formed in the late Paleocene to early-middle Eocene period in marginal marine environments (van Houten 1992; Rudmin et al. 2019). van Houten (1992) found that the majority of the oolitic ironstone deposits of the Cenozoic time are associated with glauconites and phosphorites, hardgrounds and coal measures. Our review reports 14 cases of glauconiteoolitic ironstone association, closely linked to the warming events of the Paleogene (Table 1; Fig. 1). In most of these deposits, glauconite and oolitic ironstone deposited in close proximity to lignite and phosphorite.

Glauconite-oolitic ironstone association occurs within the Paleocene Kressenberg Formation in Austria (Egger et al. 2009) (Fig. 3). Oolitic ironstone deposits proliferate in the London Basin during the late Paleocene and early Eocene (Huggett and Gale 1997). Glauconite-ironstone association declines during the onset of cold climatic conditions after EECO (ca. $50 \mathrm{Ma}$ ) (Figs. 1, 5, 6). This deposit in Egypt, Iran, and Oman coincides with middle Eocene climatic optimum (MECO) (Beavington-Penney et al. 2006; Baioumy 2007; El-Habaak et al. 2016; Zarasvandi et al. 2019). The late Oligocene glauconiteoolitic ironstone association occurs in the North American continental shelf deposit, from the palaeoNorth Sea basin and high southern latitude deposits in Australia and New Zealand (Kelly and Webb 1999; Hesselbo and Huggett 2001). Oolitic ironstones tend to form in tropical/boreotropical and warm temperate climate during most of the Paleogene. During the middle Eocene, the locus of their formation shifted towards the northern margin of the African Shelf (Fig. 5).

\section{Discussion}

4.1 The formation of glauconite during warming intervals Although the allogenic glauconite occasionally occurs in the ancient rock record (Amorosi 1997), the vast 


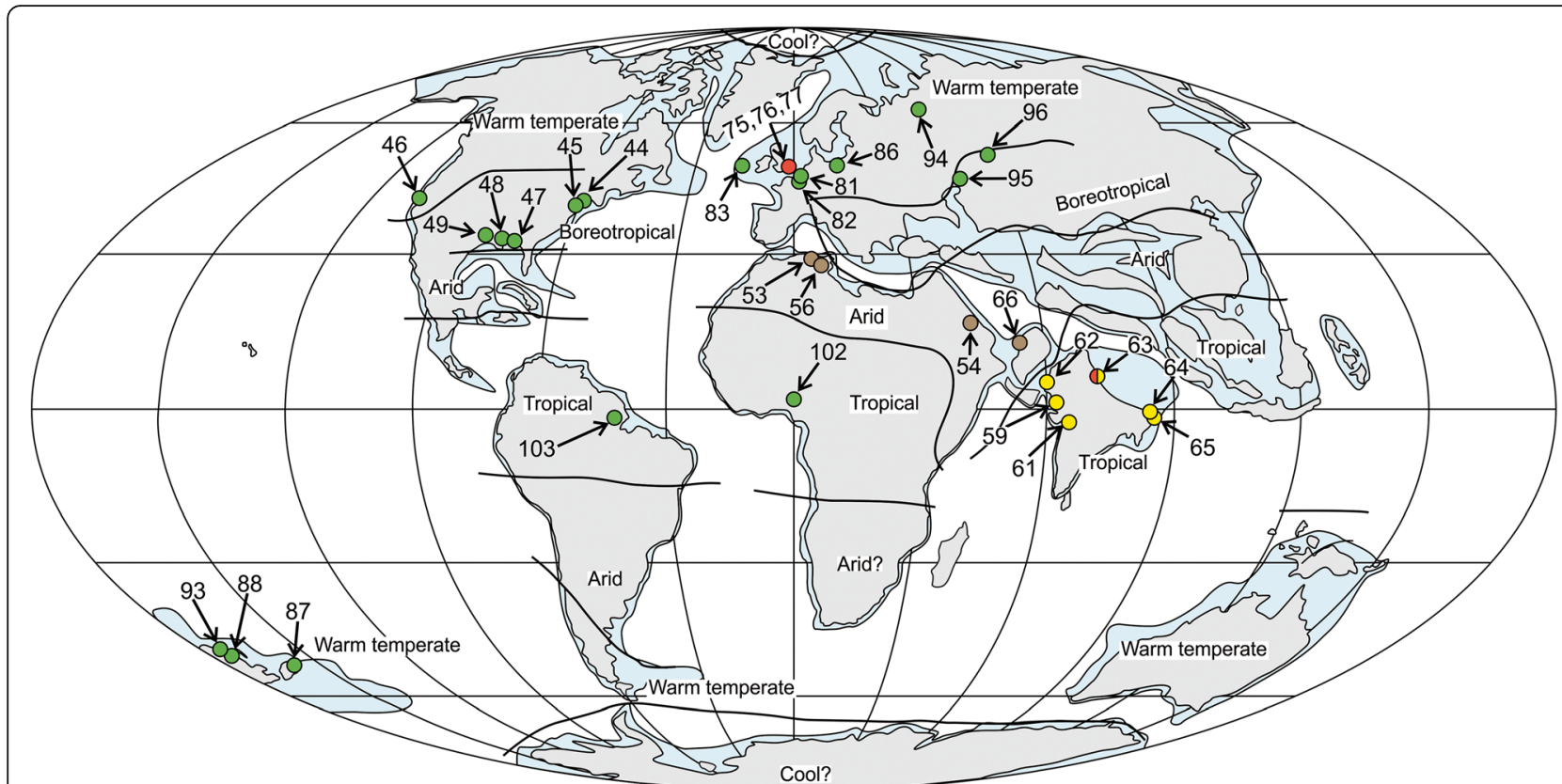

Glauconite

Oolitic ironstone-glauconite association
Phosphorite-glauconite association

Phosphorite-oolitic ironstone-glauconite association

\section{Lignite-oolitic ironstone-glauconite association}

Fig. 4 Palaeogeographic map of early Eocene showing distribution of glauconite-phosphorite, glauconite-lignite and glauconite-oolitic ironstone associations (adapted from Boucot et al. 2013). Note that extensive lignite-glauconite association occurs at the eastern part of Tethys along the Indian subcontinent (numbers correspond to those provided in Table 1)

majority of glauconites form on the seafloor in situ with negligible sediment input (Odin and Matter 1981; El Albani et al. 2005; Amorosi et al. 2007, 2012; Banerjee et al. 2012a, 2012b, 2015, 2016a, 2016b; Baldermann et al. 2013, 2017). Prolonged chemical exchange between seawater and sediments is a prerequisite for the formation of glauconite (Odin and Matter 1981). Several case studies indicate that the composition of glauconite bears subtle evidence of seawater composition of the past (El Albani et al. 2005; Meunier and El Albani 2007; Banerjee et al. 2008, 2015, 2016a, 2016b; Bansal et al. 2017, 2018, 2019, 2020a, 2020b; Tang et al. 2017a, 2017b; Liu et al. 2020; Mandal et al. 2020)

The high global abundance of glauconite in a short time span encompassing the Paleogene warming intervals rules out the local diagenetic effects on the formation of glauconite. Our literature survey shows the distribution of glauconite and other authigenic minerals on the Paleogene ocean floor across the globe. Therefore, the driving factors behind the formation of these authigenic minerals must have acted globally. The close correspondence between the occurrence of glauconite and warming intervals in Paleogene suggests a genetic link between the two (Figs. 1, 7). Several factors determine the formation of glauconite, including depositional conditions, sedimentation rate, seawater temperature, availability of iron and potassium (Odin and Matter 1981; Amorosi 1995, 1997, 2011, 2012; Amorosi and Centineo 1997; El Albani et al. 2005; Amorosi et al. 2007, 2012; Meunier and El Albani 2007; Banerjee et al. 2016a, 2016b; Mandal et al. 2020). The following section discusses the influence of the controlling factors in the formation of authigenic glauconite during the Paleogene.

The depositional environment has strong control over the formation of glauconite by regulating the rate of sedimentation, redox conditions as well as the supply of abundant ions. Although seawater contains abundant potassium, its iron content is very less, particularly in the deep marine environment. Iron is supplied into the shallow sea by the weathering of continental landmasses. However, the depositional environment remains oxic and sediment supply remains high in shallow marine environments, which discourages the growth of glauconite. In modern oceans, glauconite forms abundantly within the outer shelf and deeper environments (Odin and Matter 1981; Amorosi 2012; Banerjee et al. 2016a). However, the Paleogene glauconite formed primarily in 


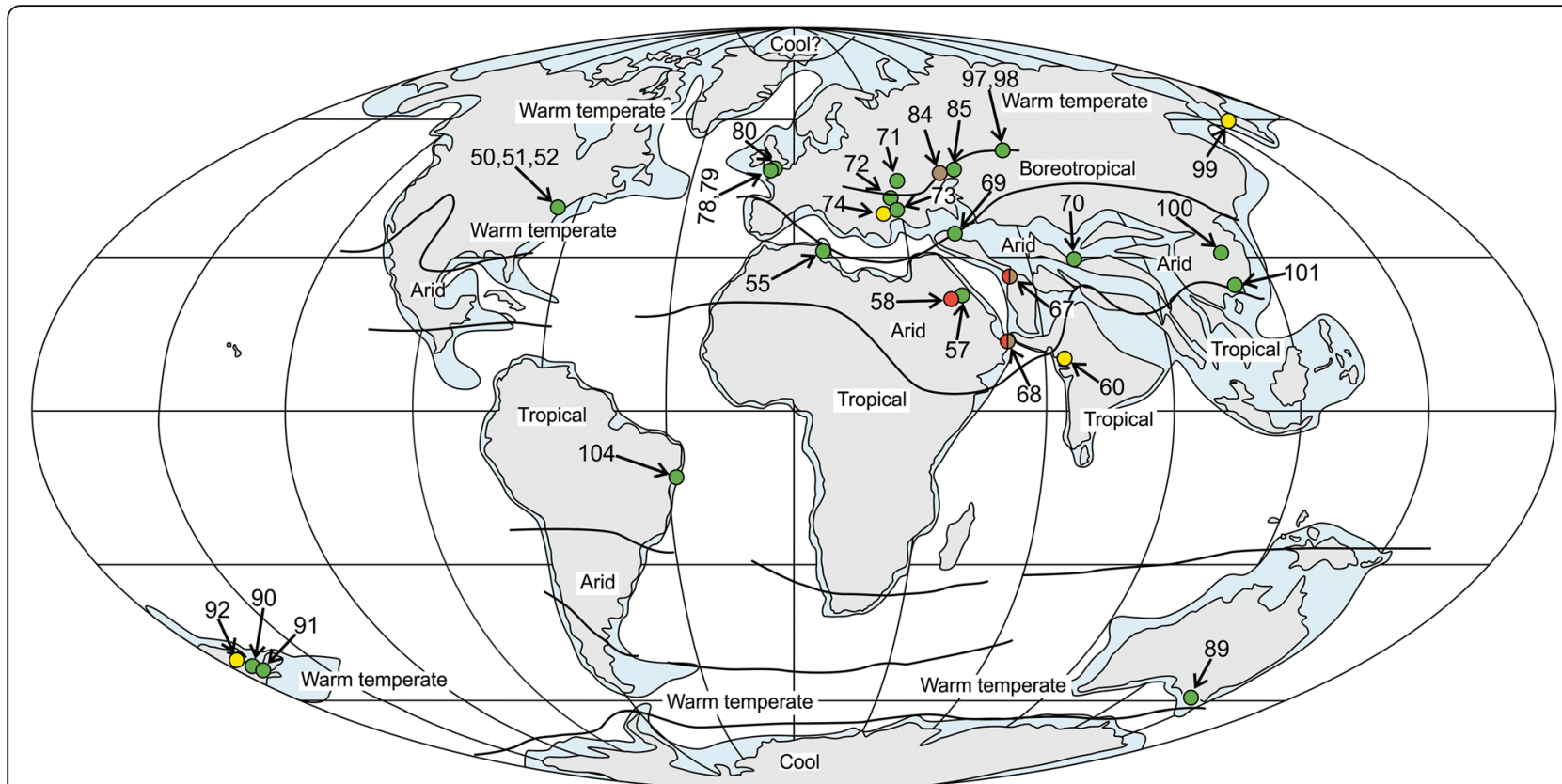

Glauconite

Phosphorite-glauconite association

Lignite-glauconite association

Oolitic ironstone-glauconite association

Phosphorite-oolitic ironstone-glauconite association

\section{Lignite-oolitic ironstone-glauconite association}

Fig. 5 Palaeogeographic map of middle and late Eocene showing the distribution of glauconite-phosphorite, glauconite-lignite and glauconiteoolitic ironstone associations (adapted from Boucot et al. 2013). Note that phosphorite-glauconite association is restricted to the eastern part of African continental shelf instead of the northern part. Scattered deposits with lignite-glauconite association occur within the tropicalboreotropical climatic belts (numbers correspond to those provided in Table 1)

shallow seas, possibly below the fair-weather wave base (Table 1; Fig. 7). Significantly, glauconites formed predominantly in shallow marine conditions during the Cretaceous period, which is also known for warm climatic conditions (Bansal et al. 2019). However, Bansal et al. (2019) could not establish the relationship between warming intervals and glauconite occurrence because of poor biostratigraphic controls of the Cretaceous successions.

Recent glauconite forms mostly along the eastern and western margins of Africa and North America, southern margin of Australia, and western margin of South America. The formation of glauconite always remained confined within $60^{\circ}$ latitudes on both sides of the equator (Porrenga 1968; Odin and Matter 1981). Except for one report of glauconite from Norway, all the Paleogene glauconites also show a similar latitudinal distribution, i.e. within the confinement of $60^{\circ}$ palaeo-latitudes. They are absent in the high latitudes (in the Arctic and Antarctic region) (Figs. 3, 4, 5, 6). The absence of glauconite in the polar region and its paucity in the extra-tropical region indicates that a high temperature of seawater facilitates the formation of this mineral. As carbonate deposition shifted to the shallow marine environment during the greenhouse climate, likewise glauconitization too shifted to shallow seas during the Paleogene hyperthermal events. The formation of glauconite is five times slower in the cold water at a depth of $2.5 \mathrm{~km}$, compared to the shallow marine region (Baldermann et al. 2013). Microbiota plays a crucial role in the fixation of iron into the smectite structure, transforming it into glauconite in the modern deep marine environment (Baldermann et al. 2017). In the case of shallow marine glauconite, such a microbial role is not apparent. The chemical composition of deep marine glauconite differs from their shallow marine counterparts by having more $\mathrm{Fe}_{2} \mathrm{O}_{3}$ and less $\mathrm{Al}_{2} \mathrm{O}_{3}$ and therefore indicates that the mechanism of formation of this mineral must be different (Baldermann et al. 2017).

The warm and humid climatic conditions during the Paleogene thermal events enhanced the rate of continental weathering (Hessler et al. 2017). Consequently, an increase in the supply of $\mathrm{K}, \mathrm{Fe}, \mathrm{Si}, \mathrm{Al}, \mathrm{Fe}$, and $\mathrm{Mg}$ ions into the shallow marine environment through riverine input likely to have raised the alkalinity of oceans (Fig. 7). Experimental results indicate that highly alkaline seawater promotes the formation of glauconite (Harder 


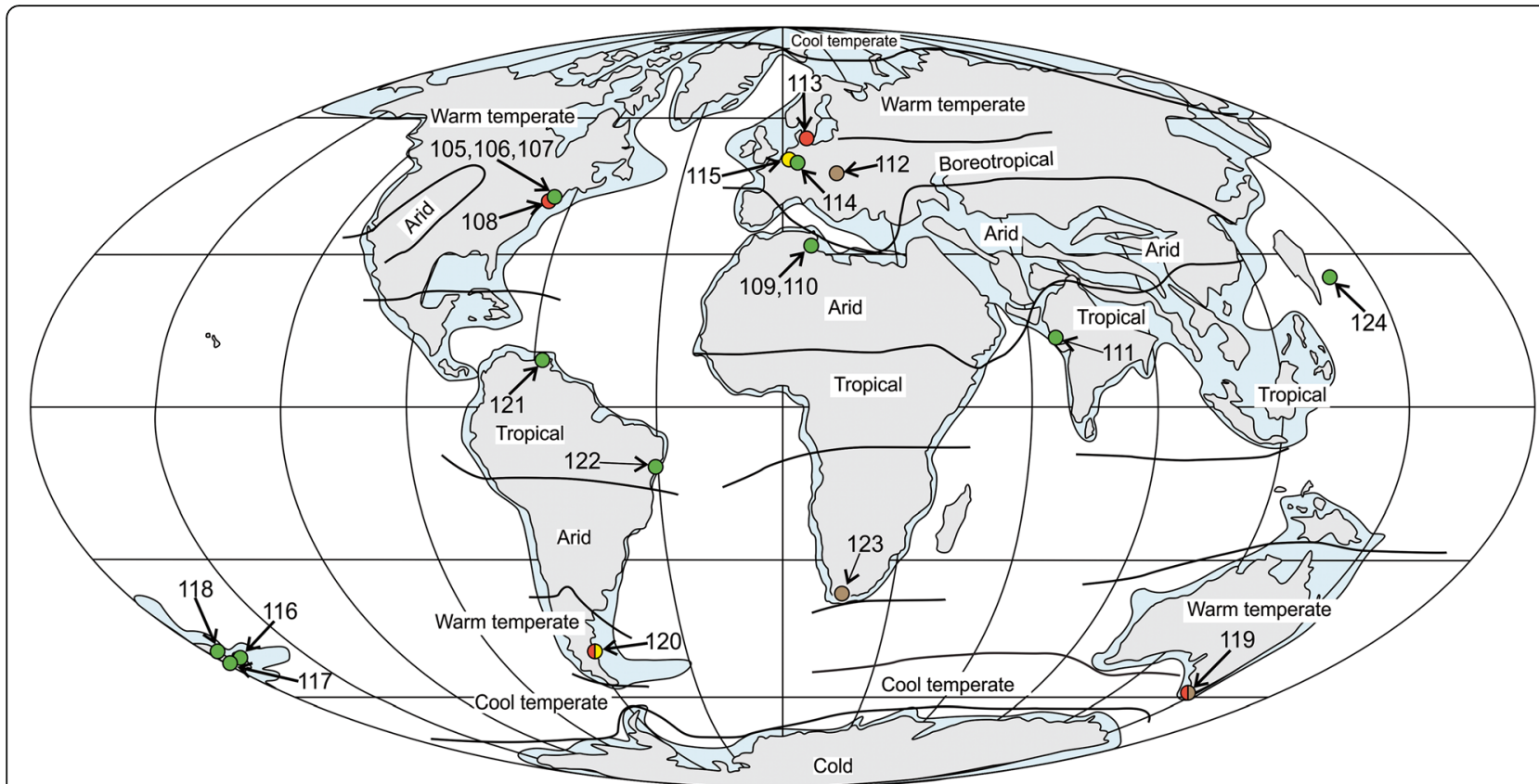

Glauconite

Oolitic ironstone-glauconite association
Phosphorite-glauconite association

Phosphorite-oolitic ironstone-glauconite association

\section{Lignite-oolitic ironstone-glauconite association}

Fig. 6 Palaeogeographic map of Oligocene showing the distribution of glauconite-phosphorite, glauconite-lignite and glauconite-oolitic ironstone associations (adapted from Boucot et al. 2013) (numbers correspond to those provided in Table 1)

1980). Extensive physical reworking of all varieties of continental rocks during the attendant marine transgression further facilitated the release of nutrients to the seawater (Peters and Gaines 2012). The enhanced riverine input during the warm climatic intervals could have provided the required $\mathrm{Fe}$ for the formation of glauconite in the shallow marine environment.
The formation of iron-bearing authigenic phases is regulated by the depositional redox condition and the iron reduction reactions (El Albani et al. 2005; Meunier and El Albani 2007; Taylor and Macquaker 2011). Experimental results indicate that sub-oxic condition is a prerequisite for glauconite formation (Harder 1980). Fe occurs as sulfide in reducing conditions in the sulfidic

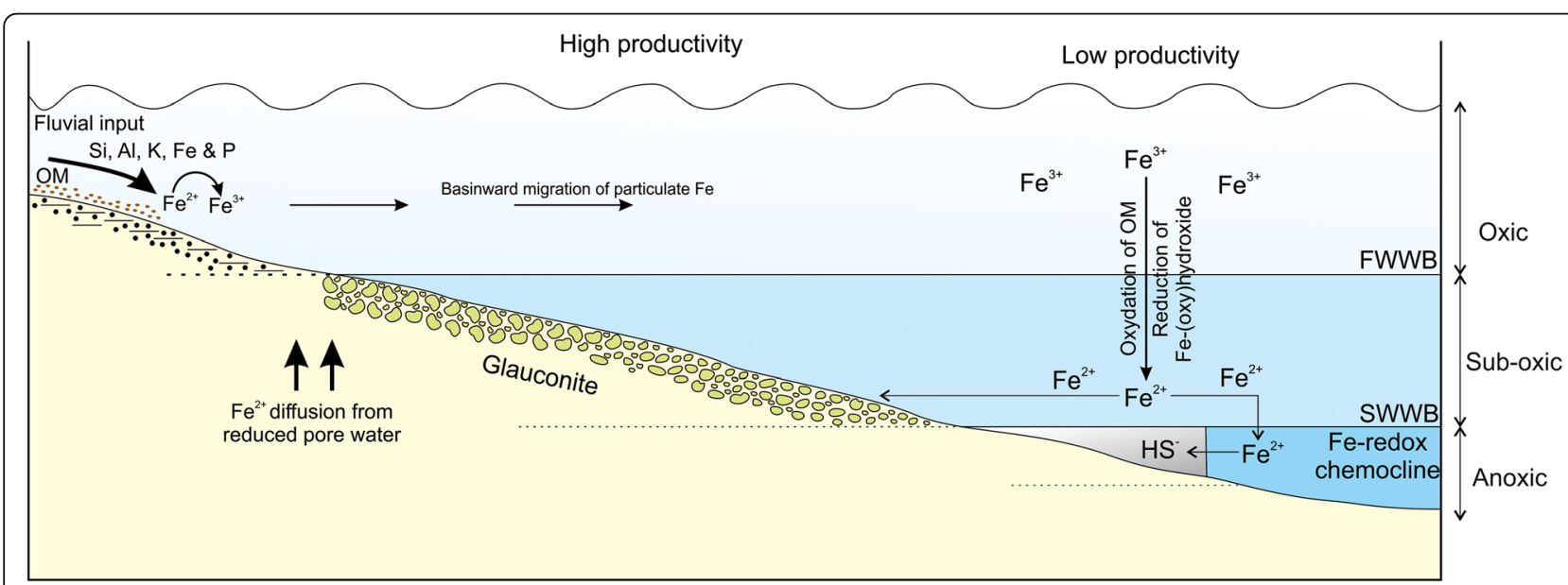

Fig. 7 Model explaining the formation of glauconite in shallow marine environment during the Paleogene time. Phosphorite and ironstone formed broadly in similar conditions. OM: Organic matter; FWWB: Fair-weather wave base; SWWB: Storm-weather wave base 
anoxic zone (Berner 1981), while goethite and chamosite forms in oxygenated seawater (Kimberley 1979; Rudmin et al. 2019). However, shallow and intermediate seas presumably became oxygen-deficient during the hyperthermal events (Nicolo et al. 2010; Schulte et al. 2013; Sluijs et al. 2014). The extensive occurrence of Paleogene black shale within the shallow marine Tethyan domain bears testimony to this (Gavrilov et al. 2013; Schulte et al. 2013). Micropalaeontological data of Kutch in India also supports oxygen-deficient shallow marine environments during PETM, ETM2, and ETM3, all of which are characterized by the high abundance of rectilinear benthic foraminifera that is known to be tolerant to low oxygen (Nigam et al. 2007; Khanolkar and Saraswati 2015, 2019). Multiple factors possibly led to this hypoxia on the Paleogene shelves (Fig. 7). The enhanced bioproductivity related to the abundant supply of nutrients created the sub-oxic condition in the shallow marine domain (Sluijs et al. 2014). Widespread hypoxia in marginal marine environments has been documented from Cretaceous global anoxic events (Sluijs et al. 2014). Significant warming during the hyperthermal events led to the discharge of freshwater and nutrients, causing a stratified seawater column and thereby promoting the suboxic to anoxic conditions. Sluggish deep-water circulation further aided the seafloor oxygen depletion (Ridgwell and Schmidt 2010). The glauconite-bearing green shales of Kutch in early and middle Eocene correspond to ETM2 and MECO. These glauconitic shales are typically characterized by tiny, triserial planktic foraminifera Jenkinsina Columbiana and Streptochilus martini (Kroon and Nederbragt 1990; Kimoto et al. 2009; Khanolkar et al. 2017). Their abundance reaching up to $35 \%$ of planktic foraminiferal count suggests high runoff and upwelling conditions in these intervals. Therefore, the availability of abundant continent-derived $\mathrm{Fe}$, as well as the development of the sub-oxic conditions in shallow seas boosted glauconite formation during warm climatic intervals.

A slow rate of sedimentation generally helps the reduced iron to be incorporated into the glauconite structure (Odin and Matter 1981; Meunier and El Albani 2007; Amorosi 2012; Banerjee et al. 2016a, 2016b). The enhanced supply of siliciclastics because of heightened continental weathering during the hyperthermal events should also have raised the sedimentation rate. Although the absolute sea-level rose only about $20 \mathrm{~m}$ to $30 \mathrm{~m}$ during the hyperthermal events, its rapidness might have led to sediment starvation in shallow seas (Sluijs et al. 2014). The occurrence of around $90 \%$ glauconite coinciding with the three warm climatic intervals marked in Fig. 1 indicate that temperature, redox condition of the depositional environment, rapid transgression as well as the availability of abundant nutrients possibly superseded the effect of possible excessive clastic supply into the marine basin related to enhanced weathering during the 'greenhouse world'.

\subsection{Factors promoting phosphorite deposition during the Paleogene time}

Phosphorite is a common associate of glauconite in the Paleogene (Glenn and Arthur 1990; Kouwenhoven et al. 1997; Kechiched et al. 2018; Metwally and Mahfouz 2018; Banerjee et al. 2019). Conditions favourable for the precipitation of phosphorite and glauconite broadly overlap, requiring depletion in clastic supply and oxygen-depleted seawater. Hypoxic and anoxic bottom seawater facilitates the recycling of phosphorus from organic matter. Sub-oxic Paleogene shelf waters, therefore, remained the favourable sites of formation for both glauconite and phosphorite. Schulte et al. (2013) reported the formation of phosphorite during the recovery phase of the PETM. Phosphorite-glauconite association in modern and ancient sediments forms within a narrow zone lying between upper slope ( $\mathrm{Fe}$ - and $\mathrm{P}$-poor, TOC enriched) and outer shelf (Fe- and P-enriched), in close vicinity of the oxygen minimum zone (Banerjee et al. 2019 and references therein). Palaeolatitude is also another factor that controls global P-cycle (Soudry et al. 2006). Low latitudes favouring open circulation prefer the accumulation of phosphorite (Cook and McElhinny 1979; Soudry et al. 2006). During most of the Paleogene, the northern part of the African continent remained close to the equator (Figs. 3, 4, 5, 6).

\subsection{Factors influencing lignite deposition}

Paleogene lignite deposits are predominantly of strand plain origin (Prasad et al. 2013), and they remain confined to the tropical zone along the palaeo-Tethyan margin (Figs. 3, 4, 5, 6; Chattoraj et al. 2009; Egger et al. 2009; Samanta et al. 2013a, 2013b). Lignite deposits form at the top of smaller order shallowing-upward cycles, below the marine flooding surfaces within an overall transgressive deposit (Prasad et al. 2013). Whereas, the occurrence of glauconite coincides with the marine flooding surfaces (Banerjee et al. 2012a, 2012b). A humid climate presumably facilitated the growth of the tropical rainforest during the warmer climatic intervals of Paleogene. Accumulation of abundant vegetal matter in a stagnant marginal marine environment possibly led to lignite formation. Coal deposits during the Paleozoic formed in tropical climates under high rainfall (Cecil et al. 1985). A low rate of clastic input coupled with wet climatic conditions and vegetation cover facilitated coal formation (Cecil 1990). However, glauconite, as well as phosphorite are rarely associated with Paleozoic coal deposits. 
Coal/lignite is particularly abundant in several Indian Paleogene basins including Cambay (Prasad et al. 2013; Samanta et al. 2013b), Kutch (Khanolkar and Saraswati 2015 and references therein), Rajasthan (Raju and Mathur 2013) and in Assam-Arakan basin (Saikia et al. 2009). The high abundance of lignite within the Indian Paleogene possibly relates to the formation of a tropical rainforest that leads to the rapid deposition of organic matter and higher land plants into the marginal marine environment (Prasad et al. 2013). Extensive development of marsh-bay complexes characterized the Indian subcontinent that remained close to the equator during the Eocene (Figs. 4, 5) (Prasad et al. 2013).

\subsection{Formation of oolitic ironstone during the Paleogene}

Glauconite forms an important component within the Paleogene oolitic ironstone deposits along the globe (van Houten 1992). Depositional conditions required for the formation of oolitic ironstone, glauconite, and phosphorite are broadly similar (van Houten 1992; Todd et al. 2019). Although most Paleozoic oolitic ironstones involve upwelling, Cenozoic deposits are controversial in terms of origin. A warm climate and marine transgression favour the formation of oolitic ironstone (Todd et al. 2019). The warm climate facilitates continental weathering and supplies abundant Fe into the shallow marine ocean (see Todd et al. op. cit.). The particulate riverine $\mathrm{Fe}$ is trapped mostly in lagoons, estuaries and flood plains before reaching the deep ocean during the rapid transgression (Poulton and Canfield 2011). Further, submarine volcanism, related to ocean floor spreading provides abundant $\mathrm{Fe}^{2+}$ into the marine realm. The upwelling current carries additional $\mathrm{P}^{4+}$ and $\mathrm{Fe}^{2+}$ from the deeper ocean and facilitates the formation of phosphorite, glauconite and oolitic ironstone. Microbial respiration/oxidation of organic matter is further responsible for the formation of anoxic and hypoxic water column in the upwelling front favouring the formation of francolite (and/or pyrite) and Fe-silicates, respectively (Todd et al. 2019). A more oxygenated water column results in the formation of Fe-(oxyhydr)oxide constituting the ironstone facies. Several studies indicated that the formation of oolitic ironstone is favoured immediately after ocean hypoxia (Schulte et al. 2013; Bekker et al. 2014). Therefore, an increase in productivity and related oxygen deficiency provides abundant ferrous iron in shelf waters, thus facilitating massive ironstone deposits during the warm climatic intervals (Homoky 2017; Konhauser et al. 2017). While the pyrite can be formed in hypoxic and anoxic seawater, chamosite and/or berthierine formation is favoured in hypoxic seawater conditions (Berner 1981; Taylor and Macquaker 2011; Todd et al. 2019; Rudmin et al. 2020). Rudmin et al. (op. cit.) established a link between volcanism and oolitic ironstone formation from the Siberian basins. Widespread volcanism in north Atlantic during the early part of Paleogene might have facilitated hypoxic seawater.

\section{Conclusions}

The review of existing literature establishes a link between Paleogene warming events and authigenic mineralization, with the following conclusions.

1) A review of global occurrences of Paleogene glauconites broadly correspond to warm climatic intervals that witnessed multiple hyperthermal events.

2) The widespread occurrence of glauconite across the globe in the late Paleocene and early Eocene relates to a combination of factors including global sealevel rise, hypoxic shelf, and warm and humid climate. A slow rate of sediment accumulation within the transgressive shallow seas facilitated the formation of glauconite on the seafloor.

3) The depositional conditions of phosphorus and oolitic ironstone are broadly similar to those of glauconite, and therefore, the abundance of these two deposits follows a similar trend.

4) Although the occurrence of authigenic deposits was largely influenced by global climatic conditions, factors like upwelling current and palaeolatitude led to the formation of phosphorite and lignite regionally.

5) Palaeo-latitudinal settings also influenced the occurrence of authigenic deposits. The deposition of phosphorite and lignite deposits was favoured in low palaeolatitudes.

6) Paleogene lignite formed mostly in coastal environments and their formation is facilitated in warm and humid climate. These deposits marked smaller order regressions within an overall transgressive deposit of warm climatic intervals.

\section{Abbreviations}

CCD: Calcite compensation depth; CFA: Carbonate fluorapatite; CIE: Carbon isotopic excursion; DAN-C2: Danian C2 event; EECO: Early Eocene climatic optimum; ELMO: Eocene layer of mysterious origin; ELPE: Early late Paleocene event; ETM1: Eocene thermal maximum 1; ETM2: Eocene thermal maximum 2; ETM3: Eocene thermal maximum 3; FO: First occurrence; FWWB: Fair-weather wave base; LDE: Latest Danian event; LO: Last occurrence; LOWE: Late Oligocene warming event; MECO: Middle Eocene climatic optimum; MPBE: Mid Paleocene biotic event; OM: Organic matter; PETM: Paleocene-Eocene thermal maximum; SWWB: Storm-weather wave base

\section{Acknowledgements}

Authors acknowledge infrastructure support by Indian Institute of Technology Bombay. Authors thank S.C. Patel and Javed M. Shaikh for providing analytical support to study many glauconite samples over the years at the DST IITB National facility for EPMA, Department of Earth Sciences, Indian Institute of Technology Bombay. 


\section{Authors' contributions}

SB, TRC and PKS carried out the data analysis and drafted the manuscript. SB conceived the study and helped to revise the manuscript. TRC and SK performed literature survey. PKS took care of biostratigraphic data interpretation. All authors read and approved the final manuscript.

\section{Funding}

SB is thankful to Ministry of Mines, Government of India for financial support through grant F No. 14/77/2015- Met. IV. TRC is thankful to Council of Scientific and Industrial Research, India for the financial support.

\section{Availability of data and materials}

Since this is a review paper all data analyzed in this study are available in published literature, which are cited in this paper.

\section{Competing interests}

The authors declare that they have no competing interests.

\section{Author details}

'Department of Earth Sciences, Indian Institute of Technology Bombay, Powai, Mumbai 400076, India. ${ }^{2}$ Department of Earth Sciences, Indian Institute of Technology Kanpur, Kanpur 208016, India.

Received: 27 April 2020 Accepted: 22 September 2020

Published online: 09 October 2020

\section{References}

Aitchison, J.C. 1988. An Eocene storm-generated littoral placer, Northeast Otago. New Zealand Journal of Geology and Geophysics 31: 381-383.

Ali, J.R., and D.W. Jolley. 1996. Chronostratigraphic framework for the Thanetian and lower Ypresian deposits of southern England. Geological Society, London, Special Publications 101: 129-144.

Amaral, G. 1967. Potassium-argon age measurements on some Brazillian glauconites. Earth and Planetary Science Letters 3: 190-192.

Amorosi, A. 1995. Glaucony and sequence stratigraphy; a conceptual framework of distribution in siliciclastic sequences. Journal of Sedimentary Research 65: 419-425.

Amorosi, A. 1997. Detecting compositional, spatial, and temporal attributes of glaucony: A tool for provenance research. Sedimentary Geology 109: 135-153.

Amorosi, A. 2011. The problem of glaucony from the Shannon sandstone (Campanian, Wyoming). Terra Nova 23: 100-107.

Amorosi, A. 2012. The occurrence of glaucony in the stratigraphic record: Distribution patterns and sequence-stratigraphic significance. International Association of Sedimentologists Special Publications 45: $37-54$.

Amorosi, A., and M.C. Centineo. 1997. Glaucony from the Eocene of the Isle of Wight (southern UK): Implications for basin analysis and sequencestratigraphic interpretation. Journal of the Geological Society 154: 887-896.

Amorosi, A., R. Guidi, R. Mas, and E. Falanga. 2012. Glaucony from the Cretaceous of the sierra de Guadarrama (Central Spain) and its application in a sequence-stratigraphic context. International Journal of Earth Sciences 101: 415-427.

Amorosi, A., I. Sammartino, and F. Tateo. 2007. Evolution patterns of glaucony maturity: A mineralogical and geochemical approach. Deep Sea Research Part II: Topical Studies in Oceanography 54: 1364-1374.

Aubry, M.P. 1985. Northwestern European Paleogene magnetostratigraphy, biostratigraphy, and paleogeography: Calcareous nannofossil evidence. Geology 13: 198-202.

Ayress, M.A. 2006. Ostracod biostratigraphy of the Oligocene-Miocene (upper Waitakian to lower Otaian) in southern New Zealand. New Zealand Journal of Geology and Geophysics 49: 359-373.

Baioumy, H.M. 2007. Iron-phosphorus relationship in the iron and phosphorite ores of Egypt. Geochemistry 67: 229-239.

Baldermann, A., M. Dietzel, V. Mavromatis, F. Mittermayr, L.N. Warr, and K. Wemmer. 2017. The role of $\mathrm{Fe}$ on the formation and diagenesis of interstratified glauconite-smectite and illite-smectite: A case study of Upper Cretaceous shallow-water carbonates. Chemical Geology 453: 21-34.
Baldermann, A., L.N. Warr, G.H. Grathoff, and M. Dietzel. 2013. The rate and mechanism of deep-sea glauconite formation at the Ivory Coast-Ghana marginal ridge. Clays and Clay Minerals 61: 258-276.

Banerjee, S., U. Bansal, K. Pande, and S.S. Meena. 2016b. Compositional variability of glauconites within the Upper Cretaceous Karai Shale Formation, Cauvery Basin, India: Implications for evaluation of stratigraphic condensation. Sedimentary Geology 331: 12-29.

Banerjee, S., U. Bansal, and A.V. Thorat. 2016a. A review on palaeogeographic implications and temporal variation in glaucony composition. Journal of Palaeogeography 5 (1): 43-71.

Banerjee, S., S.L. Chattoraj, P.K. Saraswati, S. Dasgupta, and U. Sarkar. 2012b. Substrate control on formation and maturation of glauconites in the middle Eocene Harudi formation, western Kutch, India. Marine and Petroleum Geology 30: 144-160.

Banerjee, S., S.L. Chattoraj, P.K. Saraswati, S. Dasgupta, U. Sarkar, and A. Bumby. 2012a. The origin and maturation of lagoonal glauconites: A case study from the Oligocene Maniyara fort formation, western Kutch, India. Geological Journal 47: 357-371.

Banerjee, S., S. Farouk, E. Nagm, T.R. Choudhury, and S.S. Meena. 2019. High mg-glauconite in the Campanian Duwi formation of Abu Tartur plateau, Egypt and its implications. Journal of African Earth Sciences 156: 12-25.

Banerjee, S., S. Jeevankumar, and P.G. Eriksson. 2008. Mg-rich ferric illite in marine transgressive and highstand systems tracts: Examples from the Paleoproterozoic Semri group, Central India. Precambrian Research 162: 212-226.

Banerjee, S., S. Mondal, P.P. Chakraborty, and S.S. Meena. 2015. Distinctive compositional characteristics and evolutionary trend of Precambrian glaucony: Example from Bhalukona formation, Chhattisgarh basin, India. Precambrian Research 271: 33-48.

Bansal, U., S. Banerjee, and R. Nagendra. 2020b. Is the rarity of glauconite in Precambrian deposits related to its transformation to chlorite? Precambrian Research: 336. https://doi.org/10.1016/j.precamres.2019.105509.

Bansal, U., S. Banerjee, K. Pande, A. Arora, and S.S. Meena. 2017. The distinctive compositional evolution of glauconite in the Cretaceous Ukra Hill Member (Kutch Basin, India) and its implications. Marine and Petroleum Geology 82: 97-117.

Bansal, U., S. Banerjee, K. Pande, and D.K. Ruidas. 2020a. Unusual seawater composition of the Late Cretaceous Tethys imprinted in glauconite of Narmada Basin, central India. Geological Magazine 157: 233-247.

Bansal, U., S. Banerjee, D.K. Ruidas, and K. Pande. 2018. Origin and geochemical characterization of the glauconites in the Upper Cretaceous Lameta Formation, central India. Journal of Palaeogeography 7 (1): 99-116.

Bansal, U., K. Pande, S. Banerjee, R. Nagendra, and K.C. Jagadeesan. 2019 The timing of oceanic anoxic events in the Cretaceous succession of Cauvery Basin: Constraints from ${ }^{40} \mathrm{Ar} /{ }^{39} \mathrm{Ar}$ ages of glauconite in the Karai Shale Formation. Geological Journal 54: 308-315.

Beavington-Penney, S.J., V.P. Wright, and A. Racey. 2006. The middle Eocene Seeb formation of Oman: An investigation of acyclicity, stratigraphic completeness, and accumulation rates in shallow marine carbonate settings. Journal of Sedimentary Research 76: 1137-1161.

Bekker, A., N. Planavsky, B. Rasmussen, B. Krapez, A. Hofmann, J. Slack, O. Rouxel, and K. Konhauser. 2014. Iron formations: Their origins and implications for ancient seawater chemistry. In Treatise on geochemistry, ed. H. Holland and K. Turekian, 561-628. Amsterdam: Elsevier. https:// doi.org/10.1016/B978-0-08-095975-7.00719-1.

Bektemirova, T., A. Bakirov, R. Hu, H. He, Y. Cai, W. Tan, and A. Chen. 2018. Mineralogical evolution of the Paleogene formations in the Kyzyltokoy Basin, Kyrgyzstan: Implications for the formation of glauconite. Clays and Clay Minerals 66: 43-60.

Bernaola, G., J.I. Baceta, X. Orue-Etxebarria, L. Alegret, M. Martin-Rubio, J. Arostegui, and J. Dinarès-Turell. 2007. Evidence of an abrupt environmental disruption during the mid-Paleocene biotic event (Zumaia section, western Pyrenees). Geological Society of America Bulletin 119: 785-795.

Berner, R.A. 1981. A new geochemical classification of sedimentary environments. Journal of Sedimentary Research 51: 359-365. 
Bornemann, A., P. Schulte, J. Sprong, E. Steurbaut, M.A. Youssef, and R.P. Speijer. 2009. Latest Danian carbon isotope anomaly and associated environmental change in the southern Tethys (Nile Basin, Egypt). Journal of the Geological Society of London 166: 1135-1142.

Bosboom, R., O. Mandic, G. Dupont-Nivet, J.N. Proust, C. Ormukov, and J. Aminov. 2017. Late Eocene palaeogeography of the proto-Paratethys Sea in Central Asia (NW China, southern Kyrgyzstan and SW Tajikistan). Geological Society, London, Special Publications 427: 565-588.

Boucot, A.J., C. Xu, C.R. Scotese, and R.J. Morley. 2013. Phanerozoic Paleoclimate: An Atlas of Lithologic Indicators of Climate, SEPM Concepts in Sedimentology and Paleontology 11, 478. Tulsa: Society for Sedimentary Geology.

Boukhalfa, K., A. Amorosi, M. Soussi, and K.B. Ismail-Lattrâche. 2015. Glauconitic-rich strata from Oligo-Miocene shallow-marine siliciclastic deposits of the northern margin of Africa (Tunisia): Geochemical approach for basin analysis. Arabian Journal of Geosciences 8: 1731-1742.

Boukhalfa, K., M. Soussi, E. Ozcan, S. Banerjee, and A. Tounekti. 2020. The Oligo-Miocene siliciclastic foreland basin deposits of northern Tunisia: Stratigraphy, sedimentology and paleogeography. Journal of African Earth Sciences. https://doi.org/10.1016/j.jafrearsci.2020.103932.

Bralower, T.J., I. Premoli Silva, and M.J. Malone. 2002. New evidence for abrupt climate change in the Cretaceous and Paleogene: An ocean drilling program expedition to Shatsky rise, Northwest Pacific. Geological Society of America Today 12: 4-10.

Burst, J.F. 1958. "Glauconite" pellets: Their mineral nature and applications to stratigraphic interpretations. AAPG Bulletin 42: 310-327.

Campbell, H.J., P.B. Andrews, A.G. Beu, A.R. Edwards, N.D. Hornibrook, M.G. Laird, P.A. Maxwell, and W.A. Watters. 1988. Cretaceous-Cenozoic lithostratigraphy of the Chatham Islands. Journal of the Royal Society of New Zealand 18: 285-308.

Cecil, C.B. 1990. Paleoclimate controls on stratigraphic repetition of chemical and siliciclastic rocks. Geology 18: 533-536.

Cecil, C.B., R.W. Stanton, S.G. Neuzil, F.T. Dulong, L.F. Ruppert, and B.S. Pierce. 1985. Paleoclimate controls on late Paleozoic sedimentation and peat formation in the central Appalachian Basin (USA). International Journal of Coal Geology 5: 195-230.

Chattoraj, S.L., S. Banerjee, and P.K. Saraswati. 2009. Glauconites from the late Palaeocene-early Eocene Naredi formation, western Kutch and their genetic implications. Journal of the Geological Society of India 73: 567.

Clark, M., and A. Robertson. 2005. Uppermost Cretaceous-lower Tertiary Ulukışla Basin, south-central Turkey: Sedimentary evolution of part of a unified basin complex within an evolving Neotethyan suture zone. Sedimentary Geology 173: 15-51.

Clemmensen, A., and E. Thomsen. 2005. Palaeoenvironmental changes across the Danian-Selandian boundary in the North Sea Basin. Palaeogeography, Palaeoclimatology, Palaeoecology 219: 351-394.

Cook, P.J., and M.W. McElhinny. 1979. A reevaluation of the spatial and temporal distribution of sedimentary phosphate deposits in the light of plate tectonics. Economic Geology 74: 315-330.

Cosović, V., and K. Drobne. 1995. Palaeoecological significance of morphology of orthophragminids from the Istrian peninsula (Croatia and Slovenia). Geobios 28: 93-99.

Cosović, V., K. Drobne, and A. Moro. 2004. Paleoenvironmental model for Eocene foraminiferal limestones of the Adriatic carbonate platform (Istrian peninsula). Facies 50: 61-75.

Cramer, B.S., M.P. Aubry, K.G. Miller, R.K. Olsson, J.D. Wright, and D.V. Kent. 1999. An exceptional chronologic, isotopic, and clay mineralogic record of the latest Paleocene thermal maximum, Bass River, NJ, ODP 174AX. Bulletin de la Société géologique de France 170: 883-897.

Cramer, B.S., J.D. Wright, D.V. Kent, and M.P. Aubry. 2003. Orbital climate forcing of $\delta^{13} \mathrm{C}$ excursions in the late Paleocene-early Eocene (chrons C24n-C25n). Paleoceanography 18 (4). https://doi.org/10.1029/ 2003PA000909.

Crouch, E.M., G.R. Dickens, H. Brinkhuis, M.P. Aubry, C.J. Hollis, K.M. Rogers, and $\mathrm{H}$. Visscher. 2003. The Apectodinium acme and terrestrial discharge during the Paleocene-Eocene thermal maximum: New palynological, geochemical and calcareous nannoplankton observations at Tawanui,
New Zealand. Palaeogeography, Palaeoclimatology, Palaeoecology 194: 387-403.

Crouch, E.M., C. Heilmann-Clausen, H. Brinkhuis, H.E. Morgans, K.M. Rogers, H. Egger, and B. Schmitz. 2001. Global dinoflagellate event associated with the late Paleocene thermal maximum. Geology 29: 315-318.

Czuryłowicz, K., A. Lejzerowicz, S. Kowalczyk, and A. Wysocka. 2014. The origin and depositional architecture of Paleogene quartz-glauconite sands in the Lubartów area, eastern Poland. Geological Quarterly 58: 125-144.

Dallanave, E., V. Bachtadse, E.M. Crouch, L. Tauxe, C.L. Shepherd, H.E. Morgans, C.J. Hollis, B.R. Hines, and S. Sugisaki. 2016. Constraining early to middle Eocene climate evolution of the Southwest Pacific and Southern Ocean. Earth and Planetary Science Letters 433: 380-392.

De Man, E., and S. Van Simaeys. 2004. Late Oligocene warming event in the southern North Sea Basin: Benthic foraminifera as paleotemperature proxies. Netherlands Journal of Geosciences 83: 227-239.

Dill, H.G., A. Köthe, F. Gramann, and R. Botz. 1996. A palaeoenvironmental and palaeoecological analysis of fine-grained Paleogene estuarine deposits of North Germany. Palaeogeography, Palaeoclimatology, Palaeoecology 124: 273-326.

Dix, G.R., and A. Parras. 2014. Integrated diagenetic and sequence stratigraphy of a late Oligocene-early Miocene, mixed-sediment platform (Austral Basin, southern Patagonia): Resolving base-level and paleoceanographic changes, and paleoaquifer characteristics. Sedimentary Geology 307: 17-33.

Duarte, M.A.T., and M.L. Martínez. 2002. K-Ar dating and geological significance of clastic sediments of the Paleocene Sepultura formation, Baja California, México. Journal of South American Earth Sciences 15: 725-730.

Dypvik, H., L. Riber, F. Burca, D. Rüther, D. Jargvoll, J. Nagy, and M. Jochmann. 2011. The Paleocene-Eocene thermal maximum (PETM) in Svalbard - Clay mineral and geochemical signals. Palaeogeography, Palaeoclimatology, Palaeoecology 302: 156-169.

Egger, H., C. Heilmann-Clausen, and B. Schmitz. 2009. From shelf to abyss: Record of the Paleocene/Eocene-boundary in the eastern Alps (Austria). Geologica Acta: an International Earth Science Journal 7: 215-227.

El Albani, A., A. Meunier, and F. Fürsich. 2005. Unusual occurrence of glauconite in a shallow lagoonal environment (Lower Cretaceous, northern Aquitaine Basin, SW France). Terra Nova 17: 537-544.

El-Habaak, G., M. Askalany, M. Galal, and M. Abdel-Hakeem. 2016. Upper Eocene glauconites from the Bahariya depression: An evidence for the marine regression in Egypt. Journal of African Earth Sciences 117: 1-11.

Ellison, R.A., J.R. Ali, N.M. Hine, and D.W. Jolley. 1996. Recognition of chron C25n in the upper Paleocene Upnor formation of the London Basin, UK. Geological Society, London, Special Publications 101: 185-193.

Ferrow, E., V. Vajda, C.B. Koch, B. Peucker-Ehrenbrink, and P.S. Willumsen. 2011. Multiproxy analysis of a new terrestrial and a marine CretaceousPaleogene (K-Pg) boundary site from New Zealand. Geochimica et Cosmochimica Acta 75: 657-672.

Fitch, F.J., P.J. Hooker, J.A. Miller, and N.R. Brereton. 1978. Glauconite dating of Palaeocene-Eocene rocks from East Kent and the time-scale of Palaeogene volcanism in the North Atlantic region. Journal of the Geological Society 135: 499-512.

Franzosi, C., L.N. Castro, and A.M. Celeda. 2014. Technical evaluation of glauconies as alternative potassium fertilizer from the Salamanca formation, Patagonia, Southwest Argentina. Natural Resources Research 23: $311-320$.

Frieling, J., A.I. lakovleva, G.J. Reichart, G.N. Aleksandrova, Z.N. Gnibidenko, S. Schouten, and A. Sluijs. 2014. Paleocene-Eocene warming and biotic response in the epicontinental west Siberian Sea. Geology 42: 767-770.

Garnit, H., S. Bouhlel, and I. Jarvis. 2017. Geochemistry and depositional environments of Paleocene-Eocene phosphorites: Metlaoui group, Tunisia. Journal of African Earth Sciences 134: 704-736.

Gavrilov, Y.O., E.A. Shcherbinina, O.V. Golovanova, and B.G. Pokrovskii. 2013. The late Cenomanian paleoecological event (OAE 2) in the eastern Caucasus basin of northern Peri-Tethys. Lithology and Mineral Resources 48: $457-488$ 
Gedl, P. 2014. Eocene dinoflagellate cysts from the Sołokija Graben (Roztocze, SE Poland). Geological Quarterly 58: 707-728.

Geptner, A.R., T.A. Ivanovskaya, E.V. Pokrovskaya, and N.P. Kuralenko. 2008. Glauconite from Paleogene volcano-terrigenous rocks in Western Kamchatka. Lithology and Mineral Resources 43: 228-249.

Gibson, T.G., L.M. Bybell, and D.B. Mason. 2000. Stratigraphic and climatic implications of clay mineral changes around the Paleocene/Eocene boundary of the northeastern US margin. Sedimentary Geology 134: 6592.

Gibson, T.G., L.M. Bybell, and J.P. Owens. 1993. Latest Paleocene lithologic and biotic events in neritic deposits of southwestern New Jersey. Paleoceanography 8: 495-514.

Glenn, C.R., and M.A. Arthur. 1990. Anatomy and origin of a Cretaceous phosphorite-greensand giant, Egypt. Sedimentology 37: 123-154.

Goodman, D.K. 1979. Dinoflagellate "communities"; from the lower Eocene Nanjemoy formation of Maryland USA. Palynology 3: 169-190.

Gradstein, F.M., J.G. Ogg, M.B. Schmitz, and G.M. Ogg. 2012. The Geologic Time Scale 2012. Elsevier, Amsterdam.

Hamberg, L., G. Dam, C. Wilhelmson, and T.G. Ottesen. 2005. Paleocene deep-marine sandstone plays in the Siri canyon, offshore Denmarksouthern Norway. In Geological Society, London, Petroleum Geology Conference Series, eds. A.G. Doré, and B.A. Vining. 6: 1185-1198. Geological Society of London.

Haq, B.U., J. Hardenbol, and P.R. Vail. 1987. Chronology of fluctuating sea levels since the Triassic. Science 235: 1156-1167.

Harder, H. 1980. Syntheses of glauconite at surface temperatures. Clays and Clay Minerals 28: 217-222.

Harland, W.B., A.V. Cox, P.G. Llewellyn, C.A.G. Pickton, A.G. Smith, and R. Walters. 1982. A Geologic Time Scale. Cambridge: Cambridge University Press.

Harris, W.B., P.D. Fullagar, and J.A. Winters. 1984. Rb-Sr glauconite ages, Sabinian, Claibornian and Jacksonian units, southeastern Atlantic coastal plain, USA. Palaeogeography, Palaeoclimatology, Palaeoecology 47: 53-76.

Hegab, O.A., and A.G.A. El-Wahed. 2016. Origin of the glauconite from the middle Eocene, Qarara formation, Egypt. Journal of African Earth Sciences 123: 21-28.

Hesselbo, S.P., and J.M. Huggett. 2001. Glaucony in ocean-margin sequence stratigraphy (Oligocene-Pliocene, offshore New Jersey, USA; ODP leg 174A). Journal of Sedimentary Research 71: 599-607.

Hessler, A.M., J. Zhang, J. Covault, and W. Ambrose. 2017. Continental weathering coupled to Paleogene climate changes in North America. Geology 45: 911-914.

Hines, B.R., D.K. Kulhanek, C.J. Hollis, C.B. Atkins, and H.E.G. Morgans. 2013. Paleocene-Eocene stratigraphy and paleoenvironment at Tora, Southeast Wairarapa, New Zealand. New Zealand Journal of Geology and Geophysics 56: 243-262.

Homoky, W.B. 2017. Biogeochemistry: Deep ocean iron balance. Nature Geoscience 10: 162-163.

Hower, J. 1961. Some factors concerning the nature and origin of glauconite. American Mineralogist 46: 313-334.

Huggett, J., J. Adetunji, F. Longstaffe, and D. Wray. 2017. Mineralogical and geochemical characterisation of warm-water, shallow-marine glaucony from the tertiary of the London Basin. Clay Minerals 52: 25-50.

Huggett, J.M., and J. Cuadros. 2010. Glauconite formation in lacustrine/ palaeosol sediments, Isle of Wight (Hampshire Basin), UK. Clay Minerals 45: 35-49.

Huggett, J.M., and A.S. Gale. 1997. Petrology and palaeoenvironmental significance of glaucony in the Eocene succession at Whitecliff Bay, Hampshire Basin, UK. Journal of the Geological Society 154: 897-912.

Hughes, A.D., and D. Whitehead. 1987. Glauconitization of detrital silica substrates in the Barton formation (upper Eocene) of the Hampshire Basin, southern England. Sedimentology 34: 825-835.

lakovleva, A.I., and I.A. Kulkova. 2003. Paleocene-Eocene dinoflagellate zonation of Western Siberia. Review of Palaeobotany and Palynology 123: 185-197.

Jenkyns, H.C. 2003. Evidence for rapid climate change in the MesozoicPalaeogene greenhouse world. Philosophical Transactions of the Royal
Society of London. Series A: Mathematical, Physical and Engineering Sciences 361: 1885-1916.

Jiang, Z., D. Chen, L. Qiu, H. Liang, and J. Ma. 2007. Source-controlled carbonates in a small Eocene half-graben lake basin (Shulu sag) in Central Hebei Province, North China. Sedimentology 54: 265-292.

John, C.M., S.M. Bohaty, J.C. Zachos, A. Sluijs, S. Gibbs, H. Brinkhuis, and T.J. Bralower. 2008. North American continental margin records of the Paleocene-Eocene thermal maximum: Implications for global carbon and hydrological cycling. Paleoceanography 23. https://doi.org/10.1029/ 2007PA001465.

Jorry, S., E. Davaud, and B. Caline. 2003. Controls on the distribution of nummulite facies: A case study from the late Ypresian El Garia formation (Kesra plateau, Central Tunisia). Journal of Petroleum Geology 26: 283-306.

Kalia, P., and R. Kintso. 2006. Planktonic foraminifera at the Paleocene/ Eocene boundary in the Jaisalmer Basin, Rajasthan, India. Micropaleontology 52: 521-536.

Kechiched, R., R. Laouar, O. Bruguier, S. Salmi-Laouar, L. Kocsis, D. Bosch, A. Foufou, O. Ameur-Zaimeche, and H. Larit. 2018. Glauconite-bearing sedimentary phosphorites from the Tébessa region (eastern Algeria): Evidence of REE enrichment and geochemical constraints on their origin. Journal of African Earth Sciences 145: 190-200.

Kelly, D.C. 2002. Response of Antarctic (ODP site 690) planktonic foraminifera to the Paleocene-Eocene thermal maximum: Faunal evidence for ocean/climate change. Paleoceanography 17 (4): 1071 https://doi.org/10.1029/2002PA000761.

Kelly, J.C., and J.A. Webb. 1999. The genesis of glaucony in the OligoMiocene Torquay group, southeastern Australia: Petrographic and geochemical evidence. Sedimentary Geology 125: 99-114.

Khanolkar, S., and P.K. Saraswati. 2015. Ecological response of shallowmarine foraminifera to early Eocene warming in equatorial India. The Journal of Foraminiferal Research 45: 293-304.

Khanolkar, S., and P.K. Saraswati. 2019. Eocene foraminiferal biofacies in Kutch Basin (India) in context of palaeoclimate and palaeoecology. Journal of Palaeogeography 8 (1): 1-16.

Khanolkar, S., P.K. Saraswati, and K. Rogers. 2017. Ecology of foraminifera during the middle Eocene climatic optimum in Kutch, India. Geodinamica Acta 29: 181-193.

Kharkwal, A.D. 1966. Glauconite in the Subathu beds (Eocene) of the Simla Hills of India. Nature 211: 615.

Kimberley, M.M. 1979. Origin of oolitic iron formations. Journal of Sedimentary Research 49: 111-131.

Kimoto, K., T. Ishimura, U. Tsunogai, T. Itaki, and Y. Ujiié. 2009. The living triserial planktic foraminifer Gallitellia vivans (Cushman): Distribution, stable isotopes, and paleoecological implications. Marine Micropaleontology 71: 71-79.

Knox, R.W.B. 1979. Igneous grains associated with zeolites in the Thanet beds of Pegwell Bay, Northeast Kent. Proceedings of the Geologists Association 90: 55-59.

Konhauser, K.O., N.J. Planavsky, D.S. Hardisty, L.J. Robbins, T.J. Warchola, R. Haugaard, S.V. Lalonde, C.A. Partin, P.B.H. Oonk, H. Tsikos, and T.W. Lyons. 2017. Iron formations: A global record of Neoarchaean to Palaeoproterozoic environmental history. Earth-Science Reviews 172: 140-177.

Kouwenhoven, T.J., R.P. Speijer, C.W.M. Van Oosterhout, and G.J. Van der Zwaan. 1997. Benthic foraminiferal assemblages between two major extinction events: The Paleocene El kef section, Tunisia. Marine Micropalaentology 29: 105-127.

Kroon, D., and A.J. Nederbragt. 1990. Ecology and paleoecology of triserial planktic foraminifera. Marine Micropalaentology 16: 25-38.

Lewis, D.W., and S. Belliss. 1984. Mid tertiary unconformities in the Waitaki subdivision, North Otago. Journal of the Royal Society of New Zealand 14: 251-276.

Li, Q., P.J. Davies, and B. McGowran. 1999. Foraminiferal sequence biostratigraphy of the Oligo-Miocene Janjukian strata from Torquay, southeastern Australia. Australian Journal of Earth Sciences 46: 261-273.

Liu, A., D. Tang, X. Shi, X. Zhou, L. Zhoue, M. Shang, Y. Li, and H. Fang. 2020. Mesoproterozoic oxygenated deep seawater recorded by early 
diagenetic carbonate concretions from the member IV of the Xiamaling formation, North China. Precambrian Research 341: 105667.

Liu, C., J.V. Browning, K.G. Miller, and R.K. Olsson. 1997. Upper Cretaceous to Miocene planktonic foraminiferal biostratigraphy: Results of leg 150X the New Jersey coastal plain drilling project. In Proceedings of the Ocean Drilling Program. Scientific Results, ed. K.G. Miller and S.W. Snyder, vol. 156, 111-127.

Lourens, L.J., A. Sluijs, D. Kroon, J.C. Zachos, E. Thomas, U. Röhl, J. Bowles, and I. Raffi. 2005. Astronomical pacing of late Palaeocene to early Eocene global warming events. Nature 435: 1083-1087.

Lucas, J., and L. Prévôt-Lucas. 1995. Tethyan phosphates and bioproductites. In The Tethys Ocean, ed. A.E.M. Nairn, L.E. Ricou, B. Vrielynck, and J. Dercourt, 367-391. Boston: Springer.

Lurcock, P.C., and G.S. Wilson. 2013. The palaeomagnetism of glauconitic sediments. Global and Planetary Change 110: 278-288.

MacGregor, A.R. 1983. The Waitakere limestone, a temperate algal carbonate in the lower tertiary of New Zealand. Journal of the Geological Society 140: 387-399.

Mancini, E.A. 1981. Lithostratigraphy and biostratigraphy of Paleocene subsurface strata in Southwest Alabama. Gulf Coast Association of Geological Societies Transactions 31: 359-367.

Mancini, E.A., and B.H. Tew. 1993. Eustasy versus subsidence: Lower Paleocene depositional sequences from southern Alabama, eastern gulf coastal plain. Geological Society of America Bulletin 105: 3-17.

Mandal, S., S. Banerjee, S. Sarkar, I. Mondal, and T.R. Choudhury. 2020. Origin and sequence stratigraphic implications of high-alumina glauconite within the lower quartzite, Vindhyan Supergroup. Marine and Petroleum Geology 112. https://doi.org/10.1016/j.marpetgeo.2019.104040.

Marivaux, L., E.M. Essid, W. Marzougui, H. Khayati Ammar, S. Adnet, B. Marandat, G. Merzeraud, A. Ramdarshan, R. Tabuce, M. Vianey-Liaud, and J. Yans. 2014. A morphological intermediate between eosimiiform and simiiform primates from the late middle Eocene of Tunisia: Macroevolutionary and paleobiogeographic implications of early anthropoids. American Journal of Physical Anthropology 154: 387-401.

McConchie, D.M., and D.W. Lewis. 1978. Authigenic, perigenic, and allogenic glauconites from the Castle Hill basin, North Canterbury, New Zealand. New Zealand Journal of Geology and Geophysics 21: 199-214.

Messadi, A.M., B. Mardassi, J.A. Ouali, and J. Touir. 2016. Sedimentology, diagenesis, clay mineralogy and sequential analysis model of upper Paleocene evaporite-carbonate ramp succession from Tamerza area (Gafsa Basin: Southern Tunisia). Journal of African Earth Sciences 118: 205-230.

Metwally, A.A., and K.H. Mahfouz. 2018. The Paleocene/Eocene (P/E) boundary along the eastern plateau of Kharga-Baris oases, Western Desert, Egypt. Journal of African Earth Sciences 147: 569-584.

Meunier, A., and A. El Albani. 2007. The glauconite-Fe-illite-Fe-smectite problem: A critical review. Terra Nova 19: 95-104.

Miller, K.G., J.D. Wright, M.E. Katz, B.S. Wade, J.V. Browning, B.S. Cramer, and Y. Rosenthal. 2009. Climate threshold at the Eocene-Oligocene transition: Antarctic ice sheet influence on ocean circulation. In The Late Eocene Earth: Hothouse, Icehouse, and Impacts, ed. C. Koeberl, and A. Montanari, 452: 169-178. Geological Society of America Special Paper, USA.

Morad, S., J.M. Ketzer, and L.F. De Ros. 2012. Linking diagenesis to sequence stratigraphy: An integrated tool for understanding and predicting reservoir quality distribution. Linking Diagenesis to Sequence Stratigraphy. Special Publication of the International Association of Sedimentologists 45: 1-36.

Morton, A.C., R.J. Merriman, and J.G. Mitchell. 1984. Genesis and significance of glauconitic sediments of the southwest Rockall plateau. Initial Reports of the Deep Sea Drilling Project 81: 645-652.

Nahon, D., A.V. Carozzi, and C. Parron. 1980. Lateritic weathering as a mechanism for the generation of ferruginous ooids. Journal of Sedimentary Research 50: 1287-1298.

Nicolo, M.J., G.R. Dickens, and C.J. Hollis. 2010. South Pacific intermediate water oxygen depletion at the onset of the Paleocene-Eocene thermal maximum as depicted in New Zealand margin sections. Paleoceanography 25: Pa4210. https://doi.org/10.1029/2009pa001904.
Nicolo, M.J., G.R. Dickens, C.J. Hollis, and J.C. Zachos. 2007. Multiple early Eocene hyperthermals: Their sedimentary expression on the New Zealand continental margin and in the deep sea. Geology 35: 699-702.

Nigam, R., A. Mazumder, P.J. Henriques, and R. Saraswat. 2007. Benthic foraminifera as proxy for oxygen-depleted conditions off the central west coast of India. Journal of the Geological Society of India 70: 10471054.

Odin, G.S., and A. Matter. 1981. De glauconiarum origine. Sedimentology 28: 611-641.

Peters, S.E., and R.R. Gaines. 2012. Formation of the 'great unconformity' as a trigger for the Cambrian explosion. Nature 484: 363.

Petters, S.W., and R.K. Olsson. 1979. Planktonic foraminifera from the Ewekoro type section (Paleocene) Nigeria. Micropaleontology 25: 206-213.

Pietsch, C., H.C. Harrison, and W.D. Allmon. 2016. Whence the Gosport sand (upper middle Eocene, Alabama)? The origin of glauconitic shell beds in the Paleogene of the US gulf coastal plain. Journal of Sedimentary Research 86: 1249-1268.

Polevaya, N.I., G.A. Murina, and G.A. Kazakov. 1961. Utilization of glauconite in absolute dating. Annals of the New York Academy of Sciences 91: 298310.

Porrenga, D.H. 1968. Non-marine glauconitic illite in the lower Oligocene of Aardebrug, Belgium. Clay Minerals 7: 421-430.

Poulton, S.W., and D.E. Canfield. 2011. Ferruginous conditions: A dominant feature of the ocean through Earth's history. Elements 7: 107-112.

Prasad, V., I.B. Singh, S. Bajpai, R. Garg, B. Thakur, A. Singh, N. Saravanan, and V.V. Kapur. 2013. Palynofacies and sedimentology-based high-resolution sequence stratigraphy of the lignite-bearing muddy coastal deposits (early Eocene) in the Vastan lignite mine, gulf of Cambay, India. Facies 59: 737-761.

Raju, S.V., and N. Mathur. 2013. Rajasthan lignite as a source of unconventional oil. Current Science (Bangalore) 104: 752-757.

Rasmussen, E.S., and K. Dybkjær. 2005. Sequence stratigraphy of the upper Oligocene-Lower Miocene of eastern Jylland Denmark: Role of structural relief and variable sediment supply in controlling sequence development. Sedimentology 52: 25-63.

Rasser, M.W., and W.E. Piller. 2004. Crustose algal frameworks from the Eocene Alpine foreland. Palaeogeography, Palaeoclimatology, Palaeoecology 206: 21-39.

Ridgwell, A., and D.N. Schmidt. 2010. Past constraints on the vulnerability of marine calcifiers to massive carbon dioxide release. Nature Geoscience 3: 196-200.

Rudmin, M., S. Banerjee, E. Abdullayev, A. Ruban, E. Filimonenko, E. Lyapina, R. Kashapov, and A. Mazurov. 2020. Ooidal ironstones in the MesoCenozoic sequences in western Siberia: Assessment of formation processes and relationship with regional and global earth processes. Journal of Palaeogeography 9 (1): 1-21.

Rudmin, M., S. Banerjee, and A. Mazurov. 2017. Compositional variation of glauconites in Upper Cretaceous-Palaeogene sedimentary iron-ore deposits in south-eastern western Siberia. Sedimentary Geology 355: 20-30.

Rudmin, M., A. Mazurov, and S. Banerjee. 2019. Origin of ooidal ironstones in relation to warming events: Cretaceous-Eocene Bakchar deposit, southEast Western Siberia. Marine and Petroleum Geology 100: 309-325.

Sageman, B.B., and R.C. Speed. 2003. Upper Eocene limestones, associated sequence boundary, and proposed Eocene tectonics in eastern Venezuela. In AAPG Memoir, ed. C. Bartolini, R.T. Buffler, and J. Blickwede, vol. 79, 1-17.

Saikia, B.K., R.K. Boruah, and P.K. Gogoi. 2009. A X-ray diffraction analysis on graphene layers of Assam coal. Journal of Chemical Sciences 121: 103-106.

Samanta, A., M.K. Bera, R. Ghosh, S. Bera, T. Filley, K. Pande, S.S. Rathore, J. Rai, and A. Sarkar. 2013a. Do the large carbon isotopic excursions in terrestrial organic matter across Paleocene-Eocene boundary in India indicate intensification of tropical precipitation? Palaeogeography, Palaeoclimatology, Palaeoecology 387: 91-103.

Samanta, A., A. Sarkar, M.K. Bera, J. Rai, and S.S. Rathore. 2013b. Late Paleocene-early Eocene carbon isotope stratigraphy from a nearterrestrial tropical section and antiquity of Indian mammals. Journal of Earth System Science 122: 163-171. 
Saraswati, P.K., S. Khanolkar, and S. Banerjee. 2018. Paleogene stratigraphy of Kutch, India: An update about progress in foraminiferal biostratigraphy. Geodinamica Acta 30: 100-118.

Saraswati, P.K., S. Khanolkar, D.S.N. Raju, S. Dutta, and S. Banerjee. 2014. Foraminiferal biostratigraphy of lignite mines of Kutch India: Age of lignite fossil vertebrates. Journal of Palaeogeography 3 (1): 90-98.

Sarma, J.N., and S. Basumallick. 1979. Glauconite in some Eocene carbonate rocks of Mikir hills, Assam. Indian Journal of Earth Sciences 6: 186-190.

Sarmah, R.K., and R. Borgohain. 2012. Lithostratigraphy of the Paleogene shelf sediments in Assam and Meghalaya - A review. Indian Streams Research Journal 12: 1-4.

Savrda, C.E., J.V. Browning, H. Krawinkel, and S.P. Hesselbo. 2001. Firmground ichnofabrics in deep-water sequence stratigraphy, tertiary clinoform-toe deposits, New Jersey slope. Palaios 16: 294-305.

Schiøler, P., K. Rogers, R. Sykes, C.J. Hollis, B. Ilg, D. Meadows, L. Roncaglia, and C. Uruski. 2010. Palynofacies, organic geochemistry and depositional environment of the tartan formation (late Paleocene), a potential source rock in the great South Basin, New Zealand. Marine and Petroleum Geology 27: 351-369.

Schmitz, B., B. Peucker-Ehrenbrink, C. Heilmann-Clausen, G. Åberg, F. Asaro, and C.T.A. Lee. 2004. Basaltic explosive volcanism, but no comet impact, at the Paleocene-Eocene boundary: High-resolution chemical and isotopic records from Egypt, Spain and Denmark. Earth and Planetary Science Letters 225: 1-17.

Schulte, P., L. Schwark, P. Stassen, T.J. Kouwenhoven, A. Bornemann, and R.P. Speijer. 2013. Black shale formation during the latest Danian event and the Paleocene-Eocene thermal maximum in Central Egypt: Two of a kind? Palaeogeography, Palaeoclimatology, Palaeoecology 371: 9-25.

Schweitzer, C.E., V. Cosović, and R.M. Feldmann. 2005. Harpactocarcinus from the Eocene of Istria, Croatia, and the paleoecology of the Zanthopsidae via, 1959 (Crustacea: Decapoda: Brachyura). Journal of Paleontology 79: 663-669.

Self-Trail, J.M., D.S. Powars, D.K. Watkins, and G.A. Wandless. 2012. Calcareous nannofossil assemblage changes across the Paleocene-Eocene thermal maximum: Evidence from a shelf setting. Marine Micropaleontology 92: $61-80$.

Shiloni, Y., A. Segev, G.M. Martinotti, and M. Raab. 1977. An early Eocene glauconitic bed in hor Hahar, northern Negev, Israel. Israel Journal of Earth-Sciences 26: 102-107.

Sluijs, A., L. Van Roij, G.J. Harrington, S. Schouten, J.A. Sessa, L.J. LeVay, G.J. Reichart, and C.P. Slomp. 2014. Warming, euxinia and sea level rise during the Paleocene-Eocene thermal maximum on the Gulf coastal plain: Implications for ocean oxygenation and nutrient cycling. Climate of the Past 10: 1421-1439.

Sorrentino, L., J.D. Stilwell, and C. Mays. 2014. A model of tephra dispersal from an early Palaeogene shallow submarine Surtseyan-style eruption(s), the red bluff tuff formation, Chatham Island New Zealand. Sedimentary Geology 300: 86-102.

Soudry, D., C.R. Glenn, Y. Nathan, I. Segal, and D. VonderHaar. 2006. Evolution of Tethyan phosphogenesis along the northern edges of the Arabian-African shield during the Cretaceous-Eocene as deduced from temporal variations of $\mathrm{Ca}$ and $\mathrm{Nd}$ isotopes and rates of $\mathrm{P}$ accumulation. Earth-Science Reviews 78: 27-57.

Speijer, R.P., and B. Schmitz. 1998. A benthic foraminiferal record of Paleocene Sea level and trophic/redox conditions at Gebel Aweina, Egypt. Palaeogeography, Palaeoclimatology, Palaeoecology 137: 79-101.

Sprong, J., T.J. Kouwenhoven, A. Bornemann, C. Dupuis, R.P. Speijer, P. Stassen, and E. Steurbaut. 2013. In search of the latest Danian event in a paleobathymetric transect off Kasserine Island north-Central Tunisia. Palaeogeography, Palaeoclimatology, Palaeoecology 379: 1-16.

Stap, L., L.J. Lourens, E. Thomas, A. Sluijs, S. Bohaty, and J.C. Zachos. 2010. High-resolution deep-sea carbon and oxygen isotope records of Eocene thermal maximum 2 and H2. Geology 38: 607-610.

Stap, L., A. Sluijs, E. Thomas, and L. Lourens. 2009. Patterns and magnitude of deep sea carbonate dissolution during Eocene thermal maximum 2 and $\mathrm{H} 2$, Walvis ridge, southeastern Atlantic Ocean. Paleoceanography 24 (1): A1211 https://doi.org/10.1029/2008PA001655.
Stassen, P., E. Thomas, and R.P. Speijer. 2015. Paleocene-Eocene thermal maximum environmental change in the New Jersey coastal plain: Benthic foraminiferal biotic events. Marine Micropaleontology 115: 1-23.

Steurbaut, E., C. Dupuis, I. Arenillas, E. Molina, and M.F. Matmati. 2000. The Kalaat Senan section in Central Tunisia: A potential reference section for the Danian/Selandian boundary. GFF 122: 158-160.

Steurbaut, E., R. Magioncalda, C. Dupuis, S. Van Simaeys, E. Roche, and M. Roche. 2003. Palynology, paleoenvironments, and organic carbon isotope evolution in lagoonal Paleocene-Eocene boundary settings in North Belgium. In Causes and Consequences of Globally Warm Climates in the Early Paleogene, ed. S.L. Wing, P.D. Gingerich, B. Schmitz, and E. Thomas, vol. 369, 291-317. Boulder: Geological Society of America Special Paper.

Strickler, M.E., and R.E. Ferrell Jr. 1990. Fe substitution for Al in glauconite with increasing diagenesis in the first Wilcox sandstone (lower Eocene), Livingston parish, Louisiana. Clays and Clay Minerals 38: 69-76.

Tang, D., X. Shi, G. Jiang, X. Zhou, and Q. Shi. 2017b. Ferruginous seawater facilitates the transformation of glauconite to chamosite: An example from the Mesoproterozoic Xiamaling formation of North China. American Mineralogist 102: 2317-2332.

Tang, D., X. Shi, J. Ma, G. Jiang, X. Zhou, and Q. Shi. 2017a. Formation of shallow water glaucony in weakly oxygenated Precambrian Ocean: An example from the Mesoprterozoic Tieling formation in North China. Precambrian Research 294: 214-229.

Taylor, K.G., and J.H. Macquaker. 2011. Iron minerals in marine sediments record chemical environments. Elements 7: 113-118.

Tazaki, K., and W.S. Fyfe. 1992. Microbial green marine clay from Izu-Bonin (West Pacific) deep-sea sediments. Chemical Geology 102: 105-118.

Thomas, E. 1998. Biogeography of the late Paleocene benthic foraminiferal extinction. In Late Paleocene-Early Eocene Climatic and Biotic Events in the Marine and Terrestrial Records, ed. M.P. Aubry, 214-243.

Tlig, S., S. Sahli, L. Er-Raioui, R. Alouani, and M. Mzoughi. 2010. Depositional environment controls on petroleum potential of the Eocene in the north of Tunisia. Journal of Petroleum Science and Engineering 71: 91-105.

Todd, S.E., P.K. Pufahl, J.B. Murphy, and K.G. Taylor. 2019. Sedimentology and oceanography of early Ordovician ironstone, Bell Island Newfoundland: Ferruginous seawater and upwelling in the Rheic Ocean. Sedimentary Geology 379: 1-15.

Tóth, E., T.G. Weiszburg, T. Jeffries, C.T. Williams, A. Bartha, É. Bertalan, and I. Cora. 2010. Submicroscopic accessory minerals overprinting clay mineral REE patterns (celadonite-glauconite group examples). Chemical Geology 269: $312-328$.

van der Lingen, G.J., D. Smale, and D.W. Lewis. 1978. Alteration of a pelagic chalk below a paleokarst surface, Oxford, South Island New Zealand. Sedimentary Geology 21: 45-66.

van Houten, F.B. 1992. Review of Cenozoic ooidal ironstones. Sedimentary Geology 78: 101-110.

Vanhove, D., P. Stassen, R.P. Speijer, and E. Steurbaut. 2011. Assessing paleotemperature and seasonality during the early Eocene climatic optimum (EECO) in the Belgian Basin by means of fish otolith stable $\mathrm{O}$ and C isotopes. Geologica Belgica 14: 143-157.

Wei, W. 2004. Opening of the Australia-Antarctica gateway as dated by nannofossils. Marine Micropaleontology 52: 133-152.

Wei, W., T.J. Algeo, Y. Lu, Y. Lu, H. Liu, S. Zhang, L. Peng, J. Zhang, and L. Chen. 2018. Identifying marine incursions into the Paleogene Bohai Bay basin lake system in northeastern China. International Journal of Coal Geology 200: 1-17.

Wigley, R.A., and J.S. Compton. 2006. Late Cenozoic evolution of the outer continental shelf at the head of the cape canyon, South Africa. Marine Geology 226: 1-23.

Zachos, J.C., K.C. Lohmann, J.C. Walker, and S.W. Wise. 1993. Abrupt climate change and transient climates during the Paleogene: A marine perspective. The Journal of Geology 101: 191-213.

Zachos, J.C., H. McCarren, B. Murphy, U. Röhl, and T. Westerhold. 2010. Tempo and scale of late Paleocene and early Eocene carbon isotope cycles: Implications for the origin of hyperthermals. Earth and Planetary Science Letters 299: 242-249. 
Zachos, J.C., M. Pagani, L. Sloan, E. Thomas, and K. Billups. 2001. Trends, rhythms, and aberrations in global climate $65 \mathrm{Ma}$ to present. Science 292: 686-693.

Zarasvandi, A., Z. Fereydouni, H. Pourkaseb, M. Sadeghi, B. Mokhtari, and B. Alizadeh. 2019. Geochemistry of trace elements and their relations with organic matter in Kuh-e-Sefid phosphorite mineralization, Zagros Mountain, Iran. Ore Geology Reviews 104: 72-87.

\section{Publisher's Note}

Springer Nature remains neutral with regard to jurisdictional claims in published maps and institutional affiliations.

\section{Submit your manuscript to a SpringerOpen ${ }^{\circ}$ journal and benefit from:}

- Convenient online submission

- Rigorous peer review

- Open access: articles freely available online

- High visibility within the field

- Retaining the copyright to your article

Submit your next manuscript at $\boldsymbol{\wedge}$ springeropen.com 